\title{
Article \\ Historic Storms Detected in a Changing Environment over Recent Centuries in the Belle Henriette Lagoon
}

\author{
Mohamed Maanan ${ }^{1, *} \mathbb{D}$, Pierre Pouzet ${ }^{1} \mathbb{D}$, Sabine Schmidt ${ }^{2} \mathbb{D}$ and Marc Robin ${ }^{1}$ \\ 1 CNRS, UMR 6554 Littoral, Environnement, Télédétection, Géomatique (LETG), Nantes Université, BP 81227, \\ CEDEX 3, 44312 Nantes, France; pierre.pouzet@univ-nantes.fr (P.P.); marc.robin@univ-nantes.fr (M.R.) \\ 2 UMR CNRS 5805 Environnements et Paleoenvironnements Oceaniques et Continentaux (EPOC), \\ Université de Bordeaux, Allée Geoffroy Saint-Hilaire, CS 50023, CEDEX, 33615 Pessac, France; \\ sabine.schmidt@u-bordeaux.fr \\ * Correspondence: mohamed.maanan@univ-nantes.fr
}

Citation: Maanan, M.; Pouzet, P.; Schmidt, S.; Robin, M. Historic Storms Detected in a Changing Environment over Recent Centuries in the Belle Henriette Lagoon. Atmosphere 2022, 13, 151. https:// doi.org/10.3390/atmos13020151

Academic Editor: Emmanuel Garnier

Received: 17 December 2021 Accepted: 15 January 2022

Published: 18 January 2022

Publisher's Note: MDPI stays neutral with regard to jurisdictional claims in published maps and institutional affiliations.

Copyright: (C) 2022 by the authors. Licensee MDPI, Basel, Switzerland. This article is an open access article distributed under the terms and conditions of the Creative Commons Attribution (CC BY) license (https:/ / creativecommons.org/licenses/by/ $4.0 /)$.

\begin{abstract}
This paper explores extreme storms with marine flooding events in historical times. It focuses on the challenges associated with detecting these events with a degree of certainty in a changing environment. The paleoenvironmental changes which turned the Gulf of Pictons into the Belle Henriette lagoon have required the reconstruction of events to be based on cored sediments. This study aims to establish how sedimentological washovers can be detected in a depositional environment that has changed profoundly over recent centuries. The Belle Henriette lagoon site is unique. Despite the profound environmental changes that have taken place, the impact of storms was well preserved in the five cores extracted. Eighteen historical extreme storms with marine floods were detected in the sediment. By cross-referencing with historical archives, thirteen storms were estimated in 1990, 1940, 1896, 1876, 1859, 1838, 1820, 1811, 1751, 1711, 1645, 1469, and 1351. Five older storms dating back to 1090, 1036, 941, 809, and 581 will also be discussed. By conducting a thorough historical review, we can conclude that these extreme storms caused significant damage and had a profound impact on the socioeconomic coastal communities.
\end{abstract}

Keywords: storm; paleoenvironment; sedimentology; historical archives; marine flooding; Atlantic coast; lagoon; extreme event; environmental changes; washover deposits

\section{Introduction}

The risk of extreme storms has always represented a challenge for society and is a matter of growing concern today. Coastal storms and the marine flooding they entail are one of the principal natural disasters which have occurred all over the world throughout the history of mankind, and have been increasing over the last two centuries with the rise in sea level [1]. However, the explanation for this trend on extratropical coastlines is unclear [2]. Quantification is required as to whether (i) the hazard itself has increased due to climate change, (ii) people's exposure to the hazard has increased, or (iii) the definition of what constitutes an extreme storm has changed.

Environmental changes, whether natural or caused by humans, are a significant concern as they are occurring at a new stochastic rhythm and could increase natural hazards [3]. By studying the history of coastal risks and the sedimentology, we can construct a chronology of past storms. Coupled with ancient archives, this allows precision dating of the storms that occurred in previous centuries [4]. However, studying sedimentary records to pinpoint historical storms in a changing environment is a considerable challenge [5]. Detecting washover deposits is a complex issue requiring a pluridisciplinary approach [6]. It is all the more challenging since the environment is changing rapidly and the methods for washover detection must adapt to the different paleoenvironmental configurations of a particular site. 
This paper explores the ability to study extreme historical storms entailing marine flooding events. Marine flooding is caused by significant meteorological and oceanological parameters that produce intense morphogenic activity in coastal environments [6]. A storm surge occurs when the air pressure drops and there is significant wind, but also when the wave run-up is powerful. More precisely, the study looks at the uncertainties associated with changing environments and how this affects the identification of historical washovers. A significant storm surge can involve washovers, or allochthonous deposits that originate in the marine domain and are delivered to coastal depositional environments [7]. The sedimentological detection of past storm deposits from washovers has increased in the 2000s. The United States was the first to develop this characteristic method in the early 21 st century $[7,8]$ and it has since been used worldwide, with some notable examples in Oceania [9], Asia [10], Africa [11], South America [12], and Europe [13-16]. However, these studies explore environments that have remained constant over time.

This study underlines how new approaches can improve storm reconstructions and briefly highlights some issues associated with environmental changes and decision-support analysis in relation to such extreme events. It reveals a 1000-year storm chronology in the Belle Henriette lagoon (western Marais Poitevin), a highly dynamic environment that has changed considerably over time, based on stratigraphical records coupled with historical archives.

\section{Materials and Methods}

\subsection{Study Site}

The Marais Poitevin is a fragile environment of great ecological interest. It is the second-largest wetland in France and like many wetlands around the world [17] it has a rich biodiversity. It has undergone a profound change in recent centuries. The Marais is an ancient gulf that has been progressively infilled [18] by rivers such as the Sèvre Niortaise and present-day Lay, formerly the Saint Benoist. On the western border of this marsh along the Atlantic Ocean, the Belle Henriette lagoon is a recently-formed four-kilometre-long lagoon covering nearly 200 hectares within a highly dynamic environment (Figure 1).

Cores were extracted from the Anse des Roullières precisely because this is the oldest part of the lagoon, according to historical cartography, and is, therefore, the most appropriate site for studying the paleoenvironmental evolution. This cove is composed of a mudflat colonised by salt marsh vegetation of between $0 \mathrm{~m}$ and $2 \mathrm{~m} \mathrm{NGF}$ ('Nivellement Général de la France', a network of benchmarks in mainland France overseen by the Institut Géographique National www.ign.fr, accessed on 10 December 2021) according to topographic data from the OR2C (Observatoire Régional des Risques Côtiers) team [19]. The lagoon is bordered on each side by a dune ridge culminating at nearly $10 \mathrm{~m}$ NGF. The ridge to the southeast isolates the lagoon from the ocean and the one to the northeast isolates it from the anthropized marshes and Lay estuary (Figure 1). On the Atlantic coast, the rise in sea level has slowed since the last marine transgression ended at nearly $7500 \mathrm{BP}$. In this region, a notable point of inflection is observed in the sea-level curves between $7000 \mathrm{BP}$ and $6000 \mathrm{BP}(2.6 \mathrm{~mm} /$ year sea-level rise before and $0.8 \mathrm{~mm} /$ year after $)$, indicating a relative stabilisation of the coastline [20]. Although the Belle Henriette site has undergone profound geomorphological changes over the centuries (Figure 2), this study shows that the method proposed by the OR2C to detect historical storms remains effective despite these changes.

By crossing sedimentological data with ancient cartography, we identified three main evolutions [18]: (i) the ancient Gulf of Pictons was filled up by the ocean during the transgression linked to the interglacial Holocene, (ii) the filling of the ancient bay that became a marsh as a result of alluvial deposits from the major rivers and the succinct progression of sandy spits along the shoreline; (iii) the current status of the marsh as a lagoon isolated from the ocean. In the Belle Henriette area, the sedimentary cores illustrated variations on a finer scale; (i) the former maritime bay and establishment of the sandy spit behind the lagoon are identified in the deepest facies; (ii) the temporary environment of the 
Anse des Terres Noires followed the progradation of this sandy spit, until (iii) the second sandy spit was established between 1908 and 1916, isolating the lagoon from the ocean at the Anse des Rouillères.
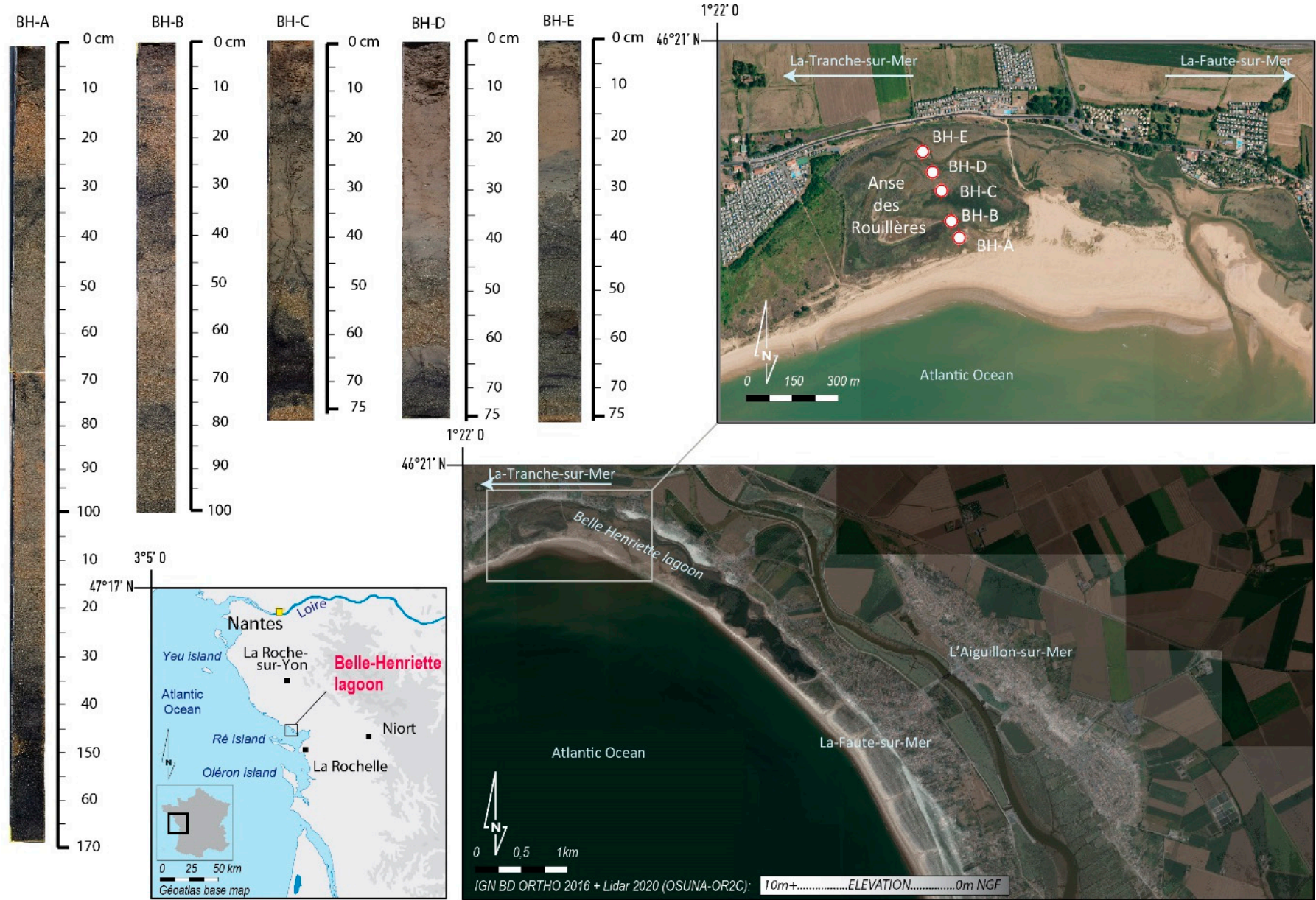
$1^{\circ} 220$

$46^{\circ} 21^{\prime} \mathrm{N}-$

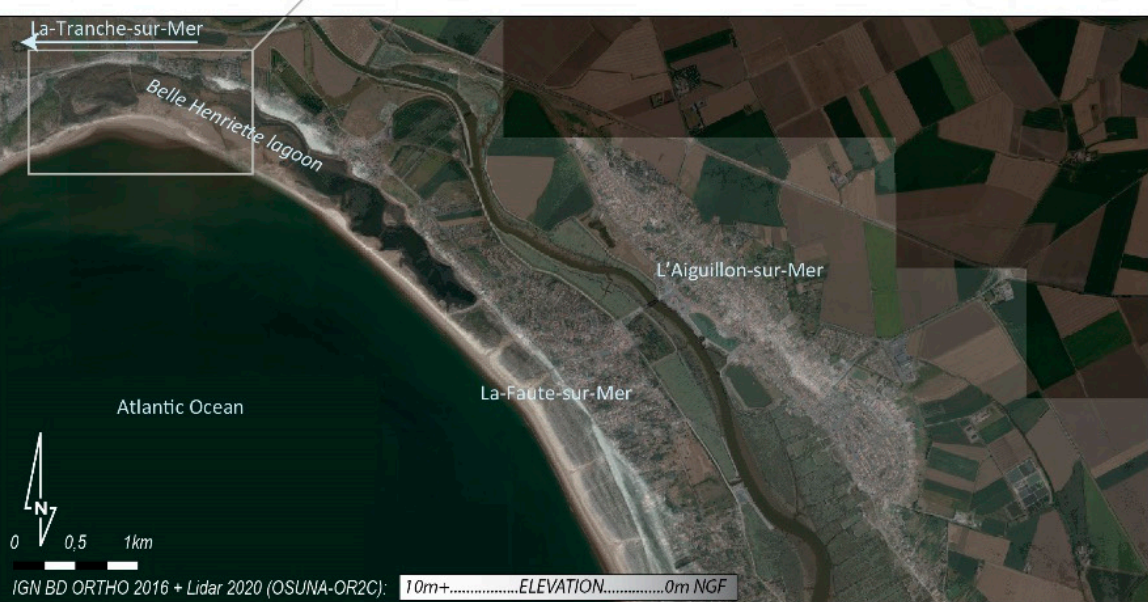

Figure 1. Presentation of the Belle Henriette lagoon and photograph of the five extracted cores The aerial photograph was extracted from Google Earth, the BD ortho comes from the IGN, and topographic data are the result of the OSUNA-OR2C team work.
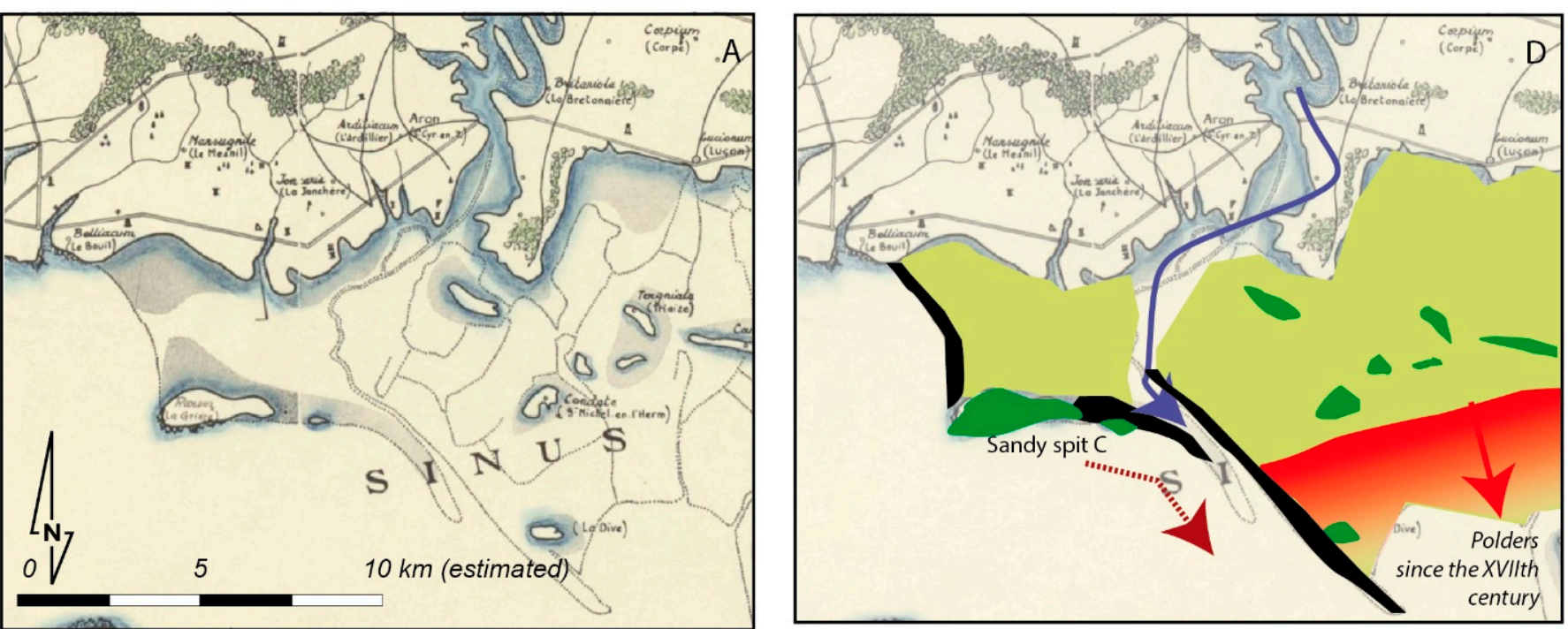

Figure 2. Cont. 

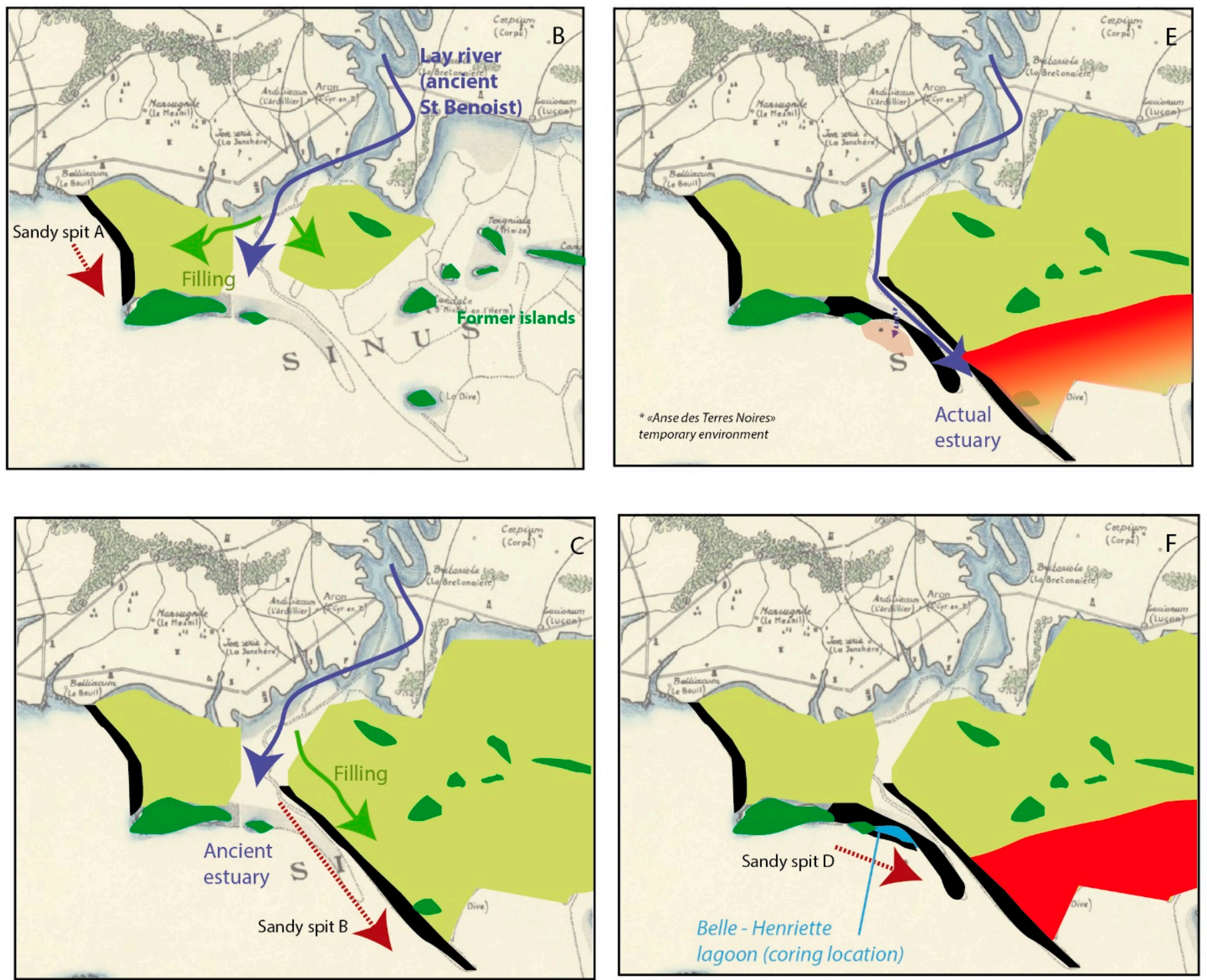

Figure 2. Summary of the paleoenvironmental evolution of the Belle Henriette lagoon. (A) Ancient "Golfe des Pictons" maritime bay (marine transgression linked to the Holocene interglacial period); (B) starting of the infilling of the western Marais Poitevin from the sandy spit A progradation and the alluvial deposits transported by the Lay (former St. Benoist) River (estimated post-540$230 \mathrm{BC}$ ); (C) filling of the eastern part of the site due to the progradation of the sandy spit B and the continuous filling of alluvial deposits (estimated between the end of Antiquity and the Early Middle Ages); (D) start of the sandy spit C progradation (estimated since AD 750) and presentation of the polderization of the western Marais Poitevin since the 18th century; (E) the "Anse des Terres Noires" temporary silty environment established during the progradation of sandy spit $C$ that has been breached near the Lay estuary (estimated near AD 1820); and (F) implementation of the BelleHenriette current lagoonal environment with the progradation of sandy spit D (estimated at the early 20th century). The map used as a background is named "Carte archéologique du Bas-Poitou" from the Regional Archives of Vendée.

\subsection{Washover Deposits Detection}

\subsubsection{Sedimentological Coring}

Five sediment cores were collected over two sedimentary coring campaigns conducted in October 2018 and October 2019, following a transect from south to north (Figure 1). We used one of two methods, depending on the type of environment analysed in the Anse 
des Rouillères [6]. The first campaign in October 2018 resulted in the collection of two cores (BH-A and $\mathrm{BH}-\mathrm{B})$ from the protective dune separating the lagoon from the ocean. An Eijkelkamp motorised vibratory percussive core sampler was used to extract the core from the compact soil [6]. The BH-A core was $170 \mathrm{~cm}$ long and the $\mathrm{BH}-\mathrm{B}$ core $100 \mathrm{~cm}$ long. During the second campaign in October 2019, we collected three cores (BH-C, BH-D, and $\mathrm{BH}-\mathrm{E})$ from the heart of the lagoon. We used an Eijkelkamp Beeker gravity corer, which is effective for sampling in wet clay or silty soils [21].

\subsubsection{Laboratory Analysis}

Each core was sliced lengthwise and each half-section photographed and described as it was opened, to preserve the colours of the sediment. To complement the sedimentological description, the Scopix@ system (Gwent, UK) was used to take $X$ radiographs [22]. A stratigraphic $\log$ was then constructed to describe the various visible facies. The sediments were characterised by lithostratigraphic visual analysis to identify major changes in facies in the sedimentary structure.

A sample was taken from every centimetre of each of the five cores to facilitate fine study of the grain size of all the facies, using a Malvern Mastersizer Hydro 2000G (Palaiseau, France). The calcined sediments were first placed in a solution of distilled water and sodium hexametaphosphate $\left(\mathrm{NaPO}_{3}\right)_{6}$ at $5 \%$ for $48 \mathrm{~h}[23,24]$. This allowed all the grains to disperse so the clays were no longer aggregated. For each sample, the software provided the grain size distribution according to 100 percentage grain-size classes, ranging from $0.02 \mu \mathrm{m}$ to $2000 \mu \mathrm{m}$. The data were then transferred to the GRADISTAT V8 software, which transformed the gross particle size distribution into an ordered distribution according to grain size class (clay, silt, sand, coarse elements) [25]. GRADISTAT also calculated several statistical indicators (MGS (Mean Grain Size), sorting, skewness, and kurtosis) according to the Folk and Ward method, which is the most common, hence our choice [26]. The coarse sandy facies revealed an allochthonous marine sediment brought in by intense marine conditions and coarser than the clayey and silty deposits common in lagoon environments [27]; it may also be coarser than the finer sands from a sandy spit or bay environment and a useful proxy for stormy deposits [28].

High-resolution elemental analyses of the split sediment cores were carried out using an Avaatech $\odot$ XRF core scanner (Dodewaard, The Netherlands). Element intensities were normalised by the total intensity (count per second of each spectrum: cps) [29,30], and element ratios $[31,32]$ were built according to a principal component analysis (PCA) statistical analysis [13]. We used multivariate statistical analysis to investigate the geochemical structure of the sediments quantitatively (continental or marine context data), and to extract the geochemical markers characterising an extreme event of marine origin [13]. A PCA was carried out using $R \odot$ software to sort these elements into two groups [33], revealing two types of deposit origin: continental and allochthonous (marine) elements. The software sorted the elements automatically following a dendrogram summary of the PCA. The geochemical ratios strontium/iron $(\mathrm{Sr} / \mathrm{Fe})$ and calcium/titanium $(\mathrm{Ca} / \mathrm{Ti})$ resulting from statistical analysis describe the dominance of exceptional marine conditions.

\subsubsection{Core Dating}

The age models of the BH-B, BH-C, BH-D, and BH-E cores were derived from a combination of two radionuclides adapted to the multi-decadal time scales. One, ${ }^{210} \mathrm{~Pb}\left(\mathrm{t}_{1 / 2}\right.$ $=22.2$ years), has been widely used to calculate short-term (decades) sediment accumulation rates in continental and oceanic environments in the last 40 years [34]. ${ }^{210} \mathrm{~Pb}$ is a naturallyoccurring radioisotope, the atmospheric inputs of which are rapidly incorporated into the sediment. This ${ }^{210} \mathrm{~Pb}$ excess $\left({ }^{210} \mathrm{~Pb}_{\mathrm{xs}}\right)$ decreases with the depth of the sediment according to its radioactive period and the sedimentation rate. The profiles of ${ }^{210} \mathrm{P}_{\mathrm{bxs}}$ in sediments allow us to estimate sedimentation rates and thus date the sediments. The accuracy of the ${ }^{210} \mathrm{~Pb}-$ based age model must be tested using an independent time-stratigraphic marker, such as ${ }^{137} \mathrm{Cs}\left(\mathrm{t}_{1 / 2}=30\right.$ years $)$, an artificial radioisotope with a pulsed input function: atmospheric 
nuclear tests (early 1950, maximum fallout in 1963 for the northern hemisphere) and the Chernobyl accident (1986) [35].

Determining the activities of the radioelements of interest $\left({ }^{210} \mathrm{~Pb},{ }^{226} \mathrm{Ra}\right.$, and $\left.{ }^{137} \mathrm{Cs}\right)$ is based on non-destructive measurements by direct gamma spectrometry on about $2 \mathrm{~g}$ of dry sediment. The detector used was a high-efficiency, broad-energy gamma spectrometer (BeGE ${ }^{\mathrm{TM}}$, Mirion Technologies, Meriden, CT, USA). Detector calibration was carried out using IAEA-certified sediments (RGU). Sediment accumulation rates (SARs) were calculated from ${ }^{210} \mathrm{~Pb}_{\mathrm{xs}}$ profiles with depth in sediments. The CF:CS (constant flux, constant sedimentation) model was used in our study as this method is widely employed for lagoon and lake depositional environments [36,37]. The age of sediment layers was obtained by dividing the depth of sediment layers by the SAR. We then estimated the year of deposition for each sediment layer by considering the age of the top core as corresponding to the sampling date (2018 for BH-A and BH-B and 2019 for BH-C, BH-D, and BH-E).

Finally, to estimate the age of the deepest facies where ${ }^{210} \mathrm{~Pb}$ activities are no longer detectable, a marine shell was taken from the BH-C core and dated using the radiocarbon $\left({ }^{14} \mathrm{C}\right)$ method. This shell enabled calibration of the sandy facies of the three lagoon cores $\mathrm{BH}-$ C, BH-D, and BH-E between 50 and $80 \mathrm{~cm}$ deep, since it was collected in an environment common to the three cores. The element extracted was a common Cerastoderma edule shell detected at $62 \mathrm{~cm}$ in the BH-C core, dated at $1810 \pm 30$ years by accelerator mass spectrometry (AMS) [38]. The analysis was carried out by the BETA Analytic laboratory (Dublin, Ireland). The date was corrected using the two atmospheric (IntCal13) and marine (Marine13) curves according to the Reimer reference [39] and the Marine Correction Database based on the work of Tisnérat-Laborde [40].

\subsection{Historical Sources}

The reconstruction of storms that affected western France was also based on ancient primary and secondary sources from historical archives [41-44], mainly descriptive texts recording data and observations. It involved the manual consultation of 19,888 manuscripts held in various archives: (i) 19,691 unpublished historical manuscripts such as narrative documents (chronicles, annals, journals, and marginal notes in parish registers) instrumental data, old maps and practice documents such as records of accounts, proceedings, repairs, and chancery; and (ii) 196 published articles. Historical archives provide qualitative data (sea state observations, descriptions of damage or societal reactions) and quantitative data (atmospheric pressure measurements, water height measurements) which must be evaluated and analysed using the historical-critical method [45,46]. The earliest marine weather hazard relatively well documented in written sources was from the winter of 1351-1352 (n.st) [47], so the reconstruction could only go back as far as the latter half of the 14th century. In addition, the reconstruction from historical sources ended at the end of the 18th century, when instrumental data was developed and came into general usage. The historical reconstruction of marine storms and submersions in western France from the mid-14th century to the late 18th century confirmed the occurrence of 128 impacting events [46].

These 128 hazards do not represent the reality of the storm activity on the spatiotemporal framework studied, or the totality of the censuses carried out, for several reasons:

(1) Historical sources record the occurrence of storms only where their impact disrupts the seigneurial levy, compromises the harvest, or entails unexpected expenses (for repairs) which are subject to tax relief [48]. The research involved in reconstructing historical storms and marine submersions in a particular area is therefore based on retrieving isolated information from documents that were not written or structured for this purpose.

(2) The major documentary gaps due to the loss or destruction of archives (religious wars, the French Revolution, the Second World War) mean that the work of researchers cannot be exhaustive.

(3) Strict criteria such as the date and description of the damage (any events that are undated or include a too-brief mention of the damage must be excluded) were applied 
for rigorous reconstruction of the events [45]. From the 18th century, newspapers and the Meteo-France database (http:/ / tempetes.meteofrance.fr, accessed on 10 December 2021) were used to complete the storm chronology.

\section{Results}

\subsection{Stratigraphic Chronologies}

3.1.1. Dating of BH-C, BH-D, and BH-E Cores Taken from the Heart of the Anse des Rouillères

The three cores BH-C, BH-D, and BH-E had a silty surface about $30-40 \mathrm{~cm}$ deep, which allowed detailed profiling of ${ }^{210} \mathrm{~Pb}_{\mathrm{xs}}$ and ${ }^{137} \mathrm{Cs}$. Significant ${ }^{210} \mathrm{P}_{\mathrm{bxs}}$ activities were measured to depths of $30 \mathrm{~cm}$ depending on the site. This enabled calculation of sediment accumulation rates of the same order of magnitude: $0.17 \mathrm{~cm} /$ year for the $\mathrm{BH}-\mathrm{C}$ core, $0.32 \mathrm{~cm} /$ year for BH-D, and $0.215 \mathrm{~cm} /$ year for BH-E (Figure 3). This enabled dating of the first few decimetres of the cores, the age of the top of the cores being 2018-the year the cores were taken. To test the dating, the ${ }^{137} \mathrm{Cs}$ profile of each core was plotted as a function of the time scale based on ${ }^{210} \mathrm{~Pb}$ (Figure 3). For cores where significant levels of ${ }^{137} \mathrm{Cs}$ were detected (BH-C, BH-D, and BH-E), there were obvious peaks in ${ }^{137} \mathrm{Cs}$ activity corresponding to the maximum ${ }^{137} \mathrm{Cs}$ weapon-test atmospheric fallout in 1963. In addition, the higher sedimentation in core $\mathrm{BH}-\mathrm{C}$ gave a higher resolution ${ }^{137} \mathrm{Cs}$ profile, enabling identification of a secondary peak in 1986, ascribed to the Chernobyl nuclear accident. This test based on ${ }^{137} \mathrm{Cs}$ therefore validates the ${ }^{210} \mathrm{~Pb}_{\mathrm{xs}}$-based dating of the $\mathrm{BH}-\mathrm{C}, \mathrm{BH}-\mathrm{D}$, and $\mathrm{BH}-\mathrm{E}$ cores, and indicates that there are fairly constant mean sediment accumulation rates at these sites.

A

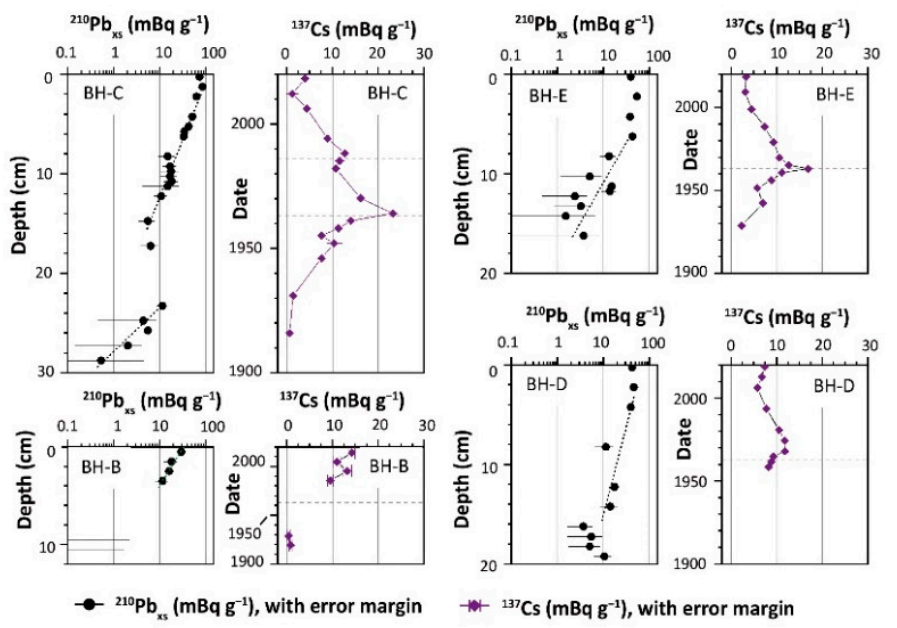

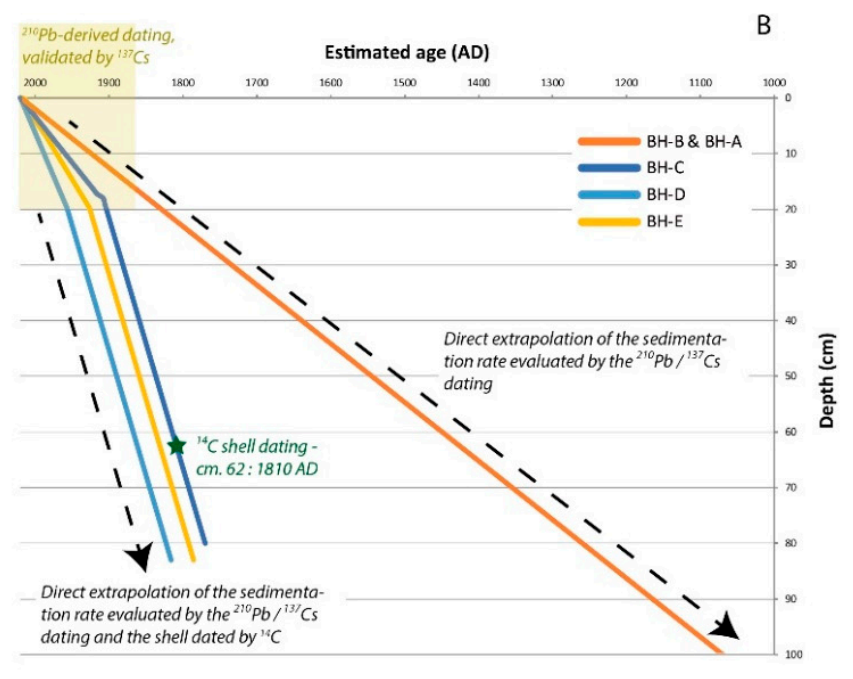

Figure 3. Detailed results of radioisotopic dating. (A) ${ }^{210} \mathrm{~Pb}_{\mathrm{xs}}$ profiles with depth in cores $\mathrm{BH}-\mathrm{B},-\mathrm{C}$, -D, and -E. ${ }^{137} \mathrm{Cs}$ profiles with the ${ }^{210} \mathrm{~Pb}_{\mathrm{xs}}$-derived age model to test its validity. The lines highlight 1963 for all cores and also 1986 for the BH-C core. (B) Age models of cores estimated from the ${ }^{210} \mathrm{~Pb}$-derived (all cores) and ${ }^{14} \mathrm{C}$ shell $\left(\mathrm{BH}-\mathrm{C},-\mathrm{D}\right.$, and $-\mathrm{E}$ ) dating (Unit: $\mathrm{mBq} \cdot \mathrm{g}^{-1}$ (Megabecquerel per Gram).

The marine shell extracted at $62 \mathrm{~cm}$ from the $\mathrm{BH}-\mathrm{C}$ core and ${ }^{14} \mathrm{C}$ dated to $1810+/-30$ years was used to date the deepest facies of the three cores. This gave an average sedimentation rate of $0.45 \mathrm{~cm}$ /year between the base layers dated by ${ }^{210} \mathrm{~Pb}_{\mathrm{xs}}$ and the level where the shell was extracted from the BH-C core. This sedimentation rate was higher than that of the superficial facies due to the high proportion of sands present. Since the three cores were extracted from the same environment and had comparable sedimentation rates for the upper facies, we used this average sedimentation rate to extrapolate the date of the deepest facies of the $\mathrm{BH}-\mathrm{D}$ and $\mathrm{BH}-\mathrm{E}$ cores (Figure 3). 


\subsubsection{Dating of BH-A and BH-B Cores Taken from the Sandy Spit D}

The two cores $\mathrm{BH}-\mathrm{A}$ and $\mathrm{BH}-\mathrm{B}$ collected from the sandy spit isolating the lagoon from the ocean mainly comprised sand topped by a $10 \mathrm{~cm}$ thick layer of silty clay (Figure 1). The silty surface facies of the BH-B core were selected to date these two cores because it was the thickest. The ${ }^{210} \mathrm{~Pb}_{\mathrm{xs}}$ activities were quite low and decreased rapidly with depth, reaching negligible levels towards $8-10 \mathrm{~cm}$. This indicated a lower sedimentation rate $(0.11 \mathrm{~cm} /$ year) than those determined for the cores collected at the heart of the Anse des Rouillères. In the absence of shells that could be used for additional dating, we used this average sedimentation rate to extrapolate the BH-A and BH-B core ages (Figure 3), as their $\log$ was homogeneous and comparable (Figures 7 and 8). Note that the dating of the deep layers of these two cores is less accurate than for the $\mathrm{BH}-\mathrm{C}, \mathrm{BH}-\mathrm{D}$, and $\mathrm{BH}-\mathrm{E}$ cores because the ${ }^{14} \mathrm{C}$ date added to the $\mathrm{BH}-\mathrm{C}, \mathrm{BH}-\mathrm{D}$, and $\mathrm{BH}-\mathrm{E}$ depth/age model improved their accuracy. As the dating carried out on these two cores was established only by ${ }^{210} \mathrm{~Pb}$ from the first ten centimetres of the BH-B core, there remains a high level of uncertainty for the deepest layers of $\mathrm{BH}-\mathrm{A}$ and $\mathrm{BH}-\mathrm{B}$.

\subsection{Sedimentological Characteristics of Sampled Cores \\ 3.2.1. BH-C, BH-D, and BH-E Cores}

The three cores BH-C, BH-D, and BH-E collected in 2019 at the heart of the Anse des Rouillères in a flat, tidal environment (Figure 1) had a similar lithostratigraphic structure (Figures 4-6). A first facies, common to all three logs, was identified on the surface structure comprising the first 16 centimetres of the cores. This silty layer, rich in organic matter and corresponding to the current surface of the Anse des Rouillères substrate, had an average grain size of about $40 \mu \mathrm{m}$ heterogeneous (sorting index 5 to 6). This first set was interrupted by several layers of coarse silts at $4 \mathrm{~cm}$ (BH-C, dated approximately 1999), 6-7 cm (BH-D dated approximately 1999 and BH-E approximately 1970), and $11 \mathrm{~cm}$ (BH-C, dated approximately 1940). Several extreme events occurred in these years in western France [13]. A second facies B was only identified in the log of the BH-C core, composed of medium homogeneous sands of about $400 \mu \mathrm{m}$ (sand rate up to $90 \%$ ) between $16 \mathrm{~cm}$ (dated 1916) and $22 \mathrm{~cm}$ (dated 1908).

The three stratigraphic logs therefore presented comparable parameters between $22 \mathrm{~cm}$ (dated around 1896) and $44 \mathrm{~cm}$ for BH-E, $46 \mathrm{~cm}$ for BH-D, and $48 \mathrm{~cm}$ for BH-C (dated between 1820 and 1840). Although the overall composition of facies $C$ seemed similar to facies $\mathrm{A}$, we noted a much higher level of clays, up to $10 \%$ in the $\mathrm{C}$ facies, while it remained fairly constant and less than 5\% in the superficial layer A. An initial C1 facies testified to calm morphogenic conditions with a silty sediment poor in sands, moving towards a more dynamic $\mathrm{C} 2$ environment alternating between fine silts, coarse silts, and fine sands.

We noted here a double progression in the dynamics of the $\mathrm{C} 2$ layer, with a much more marked heterogeneity in the BH-E core log. We also noted an evolution between the three cores. The thickness was finer for the $\mathrm{C} 2$ layer in the BH-E core log. Moving away from the heart of the lagoon, we noted greater heterogeneity and a decrease in the thickness of this layer, which then changed more rapidly into the sandy facies D, estimated around 1820.

Finally, the last facies D showed a deep, sandy layer between 44-48 cm (dated 1920-1840) and the base of the cores at $76 \mathrm{~cm}$, dated 1780-1800. Sands dominated broadly, at more than $90 \%$ of the generally well-sorted sediment composition, except for the occurrence of finer sediments (silts or fine sands) observed at two points: $62-68 \mathrm{~cm}$ in BH-D and $54-56 \mathrm{~cm}$ in $\mathrm{BH}-\mathrm{E}$. A distinction can be made between the sandy composition of these three logs. There was a higher proportion of coarse and very coarse sands in the BH-C core, up to $50 \%$ of the total sediment composition.

\subsection{2. $\mathrm{BH}-\mathrm{A}$ and $\mathrm{BH}-\mathrm{B}$ Cores}

The two cores BH-A and BH-B collected in 2018 on the sandy spit produced comparable logs (Figures 7 and 8). The logs revealing the structure of the three cores taken from the tidal flat environment. The superficial facies A is a layer dominated by coarse silts (with an 
average grain size of between 40 and $60 \mu \mathrm{m}$ ) to a depth of 10-12 cm (dated 1900-1920). This facies was similar to the A layers in BH-C, BH-D, and BH-E, but thinner. This first facies was interrupted by a layer of medium sand (approx. $350 \mu \mathrm{m}$ ) between 5 and $7 \mathrm{~cm}$ (dated around 1940). The presence of this sand can be explained by a one-time extreme event already observed in the region [13]. With the exception of this isolated marine event, the first facies A, dominated by silts, was composed of heterogeneous sediments (sorting index of about 5). It was also rich in organic matter since the wet silt sampling site supported submerged salt-marsh vegetation at high tide.

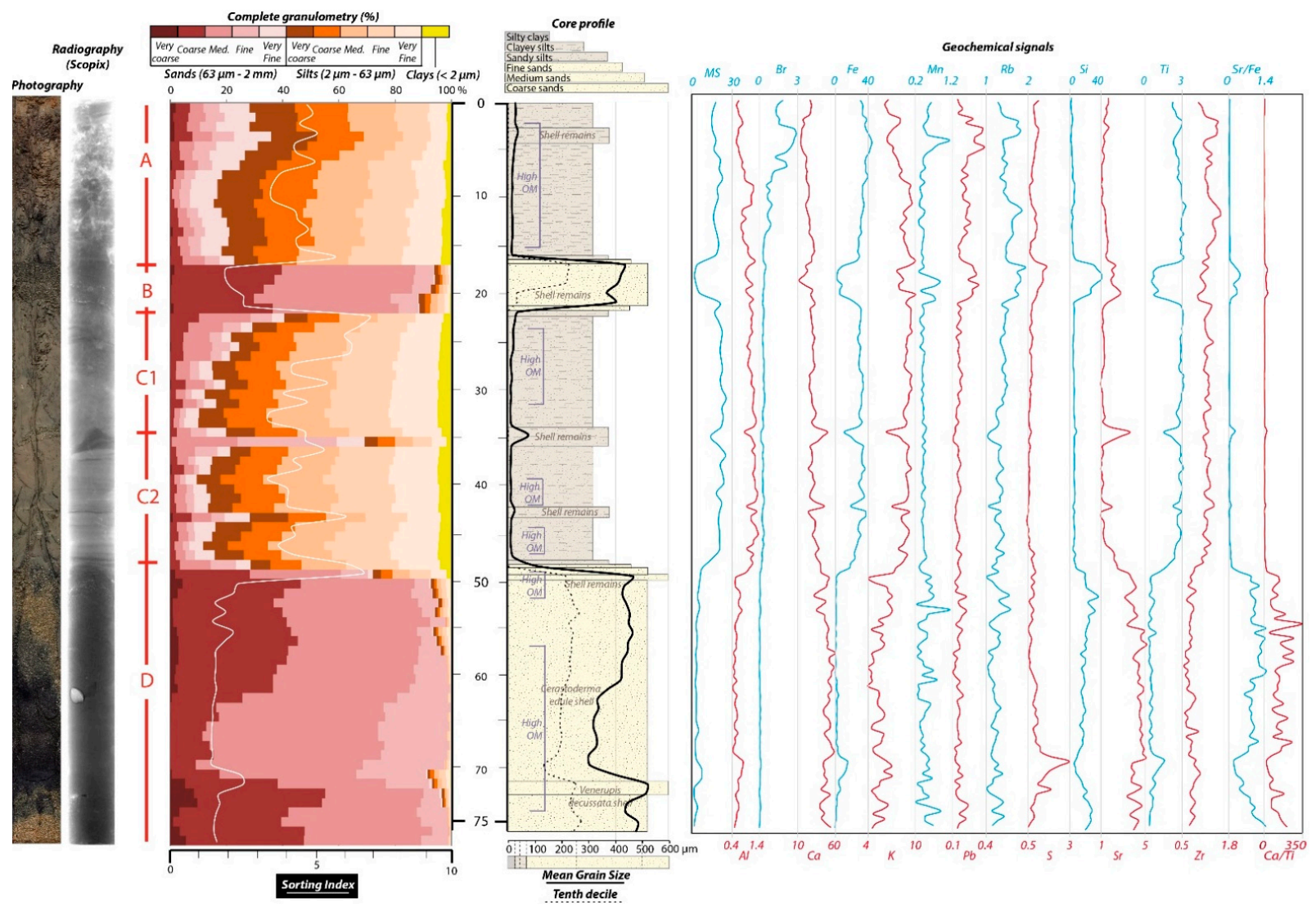

Figure 4. BH-C core log with photography, radiography, grain size results, and geochemical signals.

From 10-12 cm down to the deepest levels, fine to coarse sands dominated broadly in a much more homogeneous sedimentological set (sorting index around 1). The sandy composition reached proportions higher than $90 \%$ for most of these facies. Within this set, a sub-distinction was identified between a first facies B, composed of sand gradually passing from fine to medium grain at 20-25 cm (dated 1800-1820), with some clear variations in the sorting index and average grain size (18 cm for BH-A, 14-22 cm for BH-B). The structure of this facies was comparable with the B-facies sediment detected in $\mathrm{BH}-\mathrm{C}$. We then identified a second sandy surface, D1, composed of medium sand up to $400 \mu \mathrm{m}$ down to 135 centimetres (dated $750 \mathrm{AD}$ with extreme uncertainty). A third level, D2, was composed of coarser elements (up to $600 \mu \mathrm{m}$ ), but was also richer in organic matter and marked by a short rupture with a fine facies of silts $(147 \mathrm{~cm})$ that was found down to the bottom of the BH-A core. The grain sizes of the 'very coarse' and 'coarse' sand in the D2 facies were higher, between 135 and $170 \mathrm{~cm}(10 \%$ and 50\%, respectively) than in the D1 facies between $25 \mathrm{~cm}$ and $135 \mathrm{~cm}$ (less than $5 \%$ and $30 \%$, respectively) and the B facies between $12 \mathrm{~cm}$ and $25 \mathrm{~cm}$ (very coarse grains almost zero and coarse grains around 30\%). The sedimentological characteristics of the D1 facies were comparable with those of the D layers for the three cores BH-C, BH-D, and BH-E. They showed very close similarities to the $\mathrm{D}$ facies of the $\mathrm{BH}-\mathrm{C}$ core, which comprised coarser sands than the $\mathrm{D}$ facies of $\mathrm{BH}-\mathrm{D}$ and $\mathrm{BH}-\mathrm{E}$. 


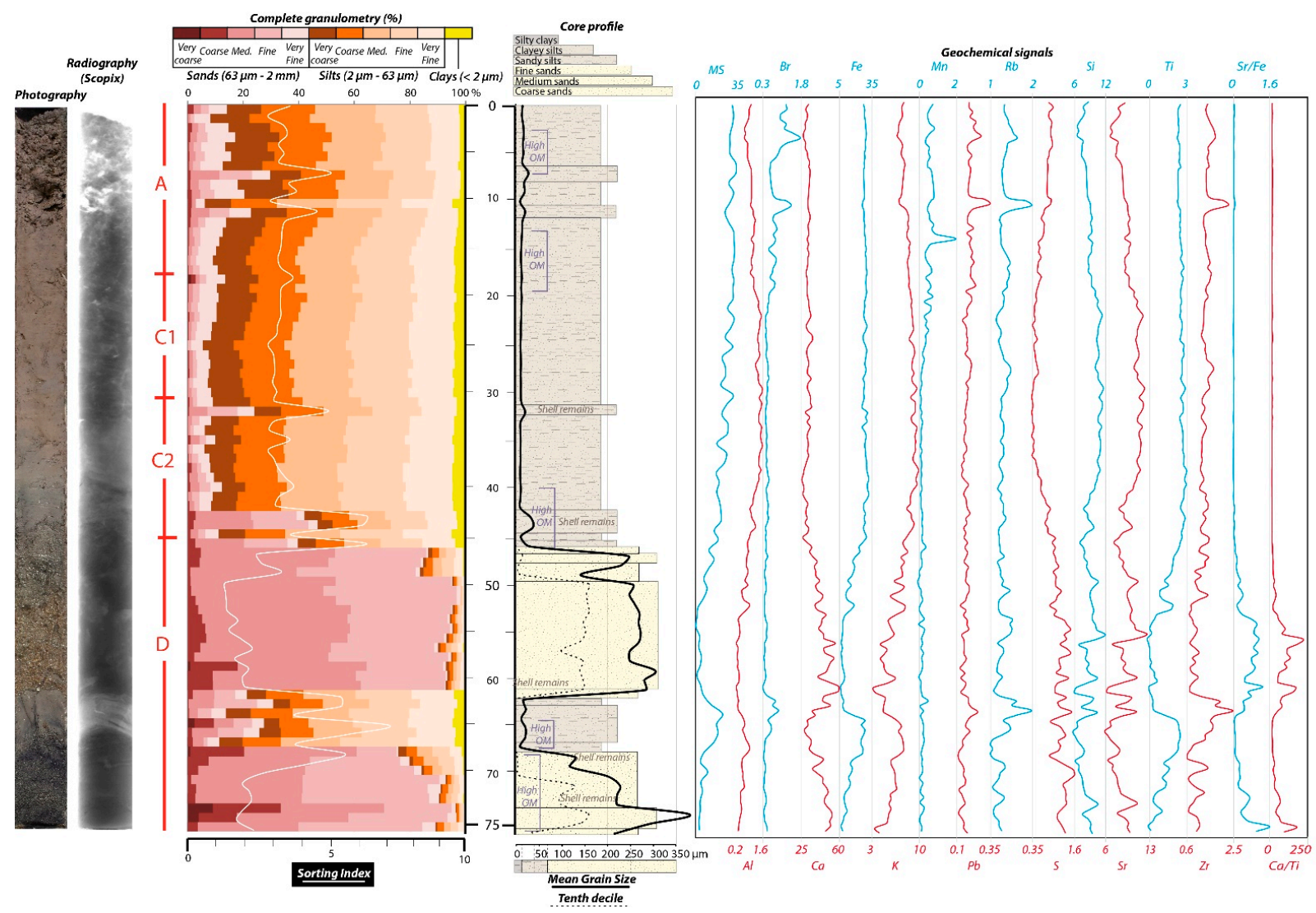

Figure 5. BH-D core log with photography, radiography, grain size results, and geochemical signals.

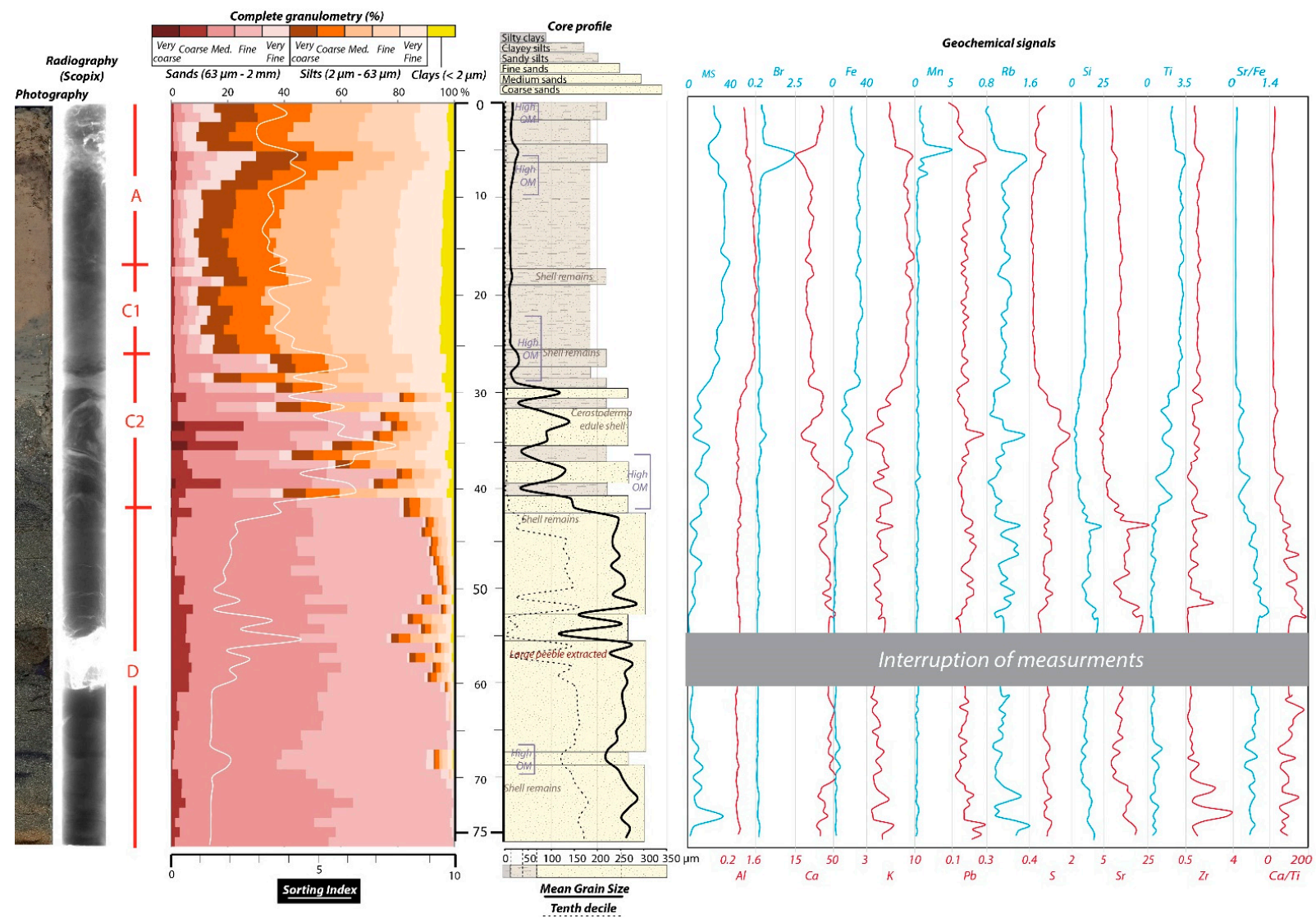

Figure 6. BH-E core log with photography, radiography, grain size results, and geochemical signals. 


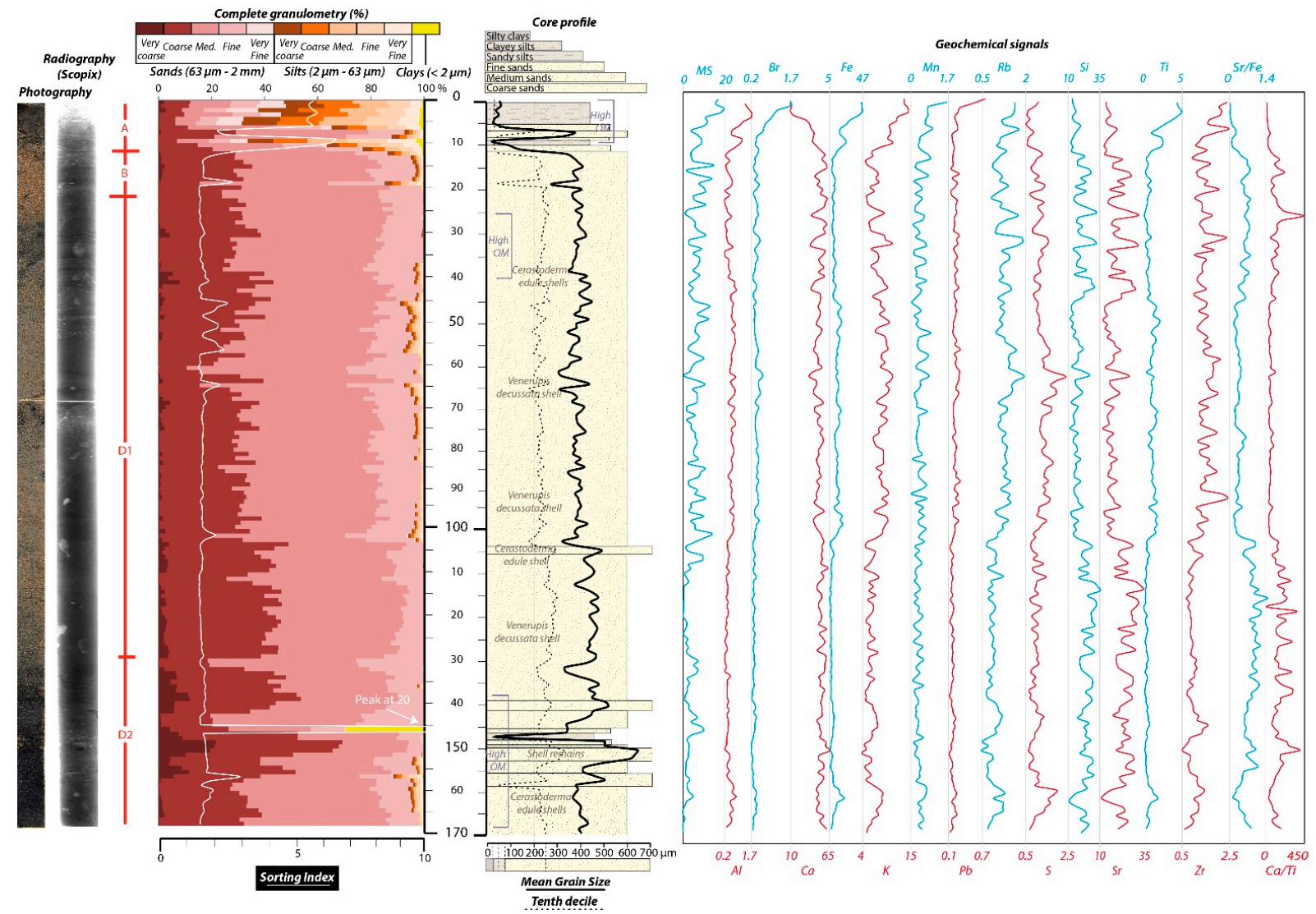

Figure 7. BH-A core log with photography, radiography, grain size results, and geochemical signals.

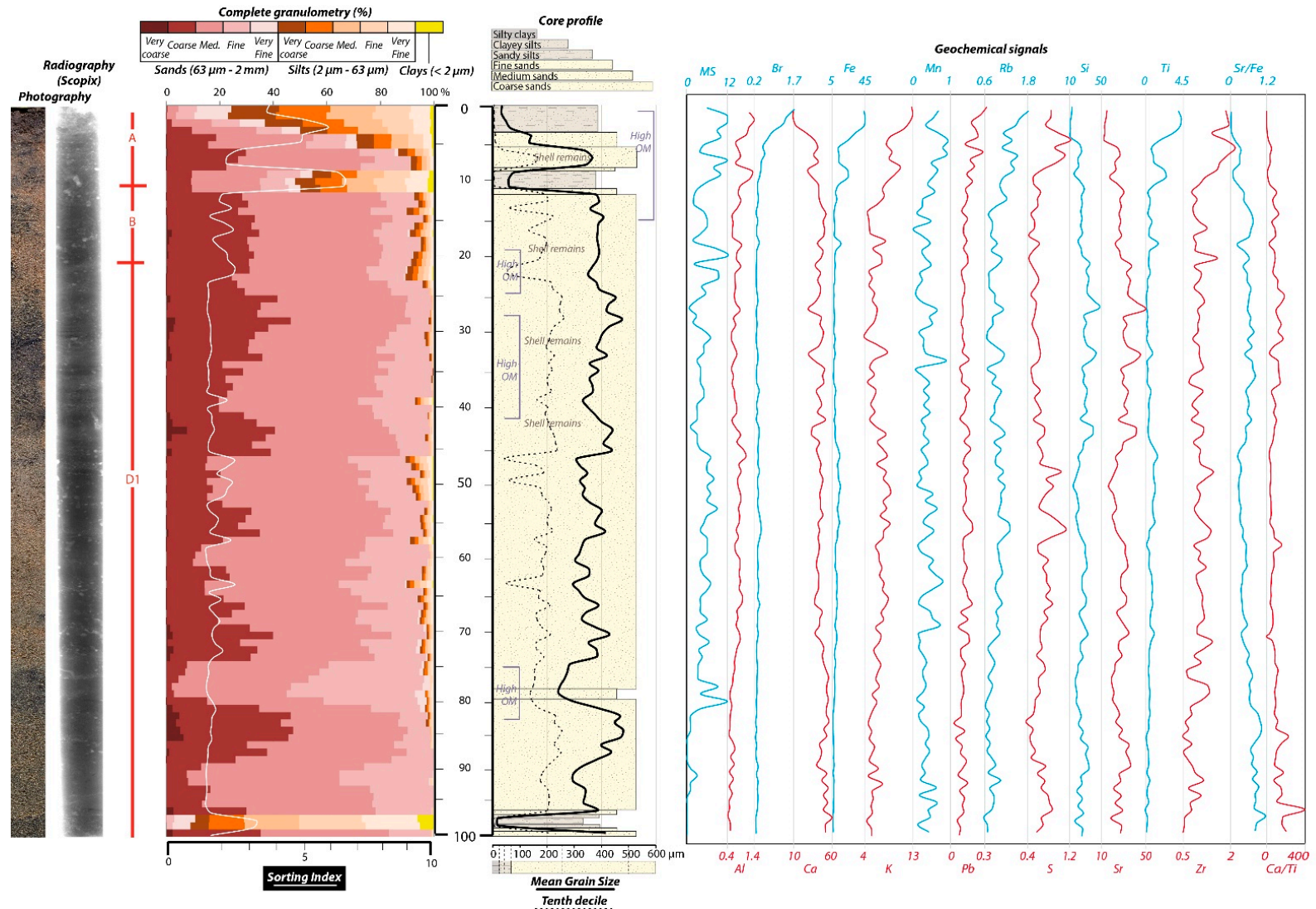

Figure 8. BH-B core log with photography, radiography, grain size results, and geochemical signals. 


\subsection{Detection of Old Storms by Crossing Sedimentological Indices}

Based on statistical analyses, the grain size (mean grain size (MGS), sorting index, and sand rate) and geochemical ratios ( $\mathrm{Sr} / \mathrm{Fe}$ (strontium/iron) and $\mathrm{Ca} / \mathrm{Ti}$ (calcium/titanium)) were used to determine historical washovers (Figure 9). The scientific community considers concomitant peaks in particle size and geochemical indices as good storm proxies because they indicate a notable marine impulse [4,6]. With this type of analysis, the BH-A and $\mathrm{BH}-\mathrm{B}$ cores, being of long temporality, enabled detection of traces of the storms of 1940 (peaks in MGS, sand content, and tenth decile, dated 1940), 1859 (peaks in Sr dated 1853), 1751 (peaks in Ca/Ti dated 1758), 1711 (peaks in Sr dated 1701), 1645 (peaks in $\mathrm{Sr}$ dated 1620), 1469 (peaks in MGS, sand content, and Sr, dated 1400-1473), and 1351 (peaks in Sr dated 1350). Five older impacts were also considered but the historical archives prevented any direct association with ancient storms dated 1090 (peaks in MGS, sand content, $\mathrm{Sr}$ and $\mathrm{Ca} / \mathrm{Ti}$ ), 1036 (peaks in MGS and Sr), 941 (peaks in Sr and $\mathrm{Ca} / \mathrm{Ti}$ ), 809 (peaks in $\mathrm{Sr}, \mathrm{Sr} / \mathrm{Fe}$, and $\mathrm{Ca} / \mathrm{Ti}$ ) and 581 (peaks in MGS, sand content, and $\mathrm{Ca} / \mathrm{Ti}$ ). In the three cores collected in the heart of the lagoon, the temporality was much shorter and limited to the 18th century, enabling identification of the storm of 1859 (peaks in MGS, tenth decile, sand content, $\mathrm{Sr}, \mathrm{Sr} / \mathrm{Fe}$, and $\mathrm{Ca} / \mathrm{Ti}$, dated 1850 and 1867). A finer resolution of these three samples also allowed us to detect the more recent events of 1990 (small peaks in MGS and Sr but significant sand content evolutions dated 1988, 1995, and 1985), 1896 (significant MGS, sand, tenth decile sand content, $\mathrm{Sr}$ increases, and $\mathrm{Sr} / \mathrm{Fe}$ and $\mathrm{Ca} / \mathrm{Ti}$ progressions dated 1899, 1902, and 1880-1910), 1876 (MGS, sand content, Sr, and Ca/Ti peaks dated 1876, 1878, and 1872), 1838 (peaks in MGS, sand content, tenth decile, $\mathrm{Sr} / \mathrm{Fe}$, and $\mathrm{Ca} / \mathrm{Ti}$ dated 1832, 1836, and 1838), 1820 (peaks in $\mathrm{Sr} / \mathrm{Fe}$ and $\mathrm{Ca} / \mathrm{Ti}$ with a slight increase in coarse sands dated 1823 and 1827), and 1811 (peaks in sand, MGS, tenth decile $\mathrm{Sr}, \mathrm{Sr} / \mathrm{Fe}$, and $\mathrm{Ca} / \mathrm{Ti}$ dated 1810 and 1816).

The most notable event detected in the lagoon sequence was the 1896 event, dated 1899,1878 , and 1880-1910 in the three lagoon cores BH-C, BH-D, and BH-E. In BH-C, a significant sandy marine incursion having sharp contact with the surrounding silts was detected. The MGS, tenth decile, and sand percentages increased at $22 \mathrm{~cm}$ (Figure 9). These increases are much greater than the proxy progressions linked to the other storms. The sand content shows a progression from $40 \%$ to $95 \%$, with increases in tenth decile and MGS from $20 \mu \mathrm{m}$ to $200 \mu \mathrm{m}$ and from $40 \mu \mathrm{m}$ to $500 \mu \mathrm{m}$, respectively. This is concomitant with significant pulses of S (from 0.55 to 1), Si (from 5 to 40), and Sr (from 1 to 2.3). In BH-D, a less significant grain size marine pulse was recorded, but the geochemical signal remained significant since $\mathrm{Si}$ and $\mathrm{Sr}$ increased respectively from 7 to 10 and from 7 to 10.5. BH-E was also highly impacted with a succession of sandy pulses (from 40 to $150 \mu \mathrm{m}$ of MGS) dated between 1880 and 1910. This is characteristic of a high morphogenic environment originating from stormy conditions.

\subsection{Socioeconomic Impacts of Events Detected in Sedimentological and Historical Records}

As developed by Athimon (2021) [45], historical archives enabled us to identify 128 ancient storms between the 14th and 18th centuries. No storm information was identified before 1340 in these sources. Between 1340 and 1400, 8 storms were identified, and 22 occurrences were mentioned during the 15th century. However, the data are not exhaustive and the level of representation of the sources is qualified as 'random' for the 14th and 15th centuries. In the 16th, 17th, and 18th centuries, 31, 33, and 34 different storms were mentioned, respectively, but the sources are only partially representative and not exhaustive for these three centuries. Since the 18th century, local newspapers and the Meteo-France database have recorded nearly a hundred storms that partially or totally affected western France. The sections below relate to the main storms that impacted the Belle Henriette environment, the isotopic dating of which correspond to historical dates found in ancient and recent written archives. 

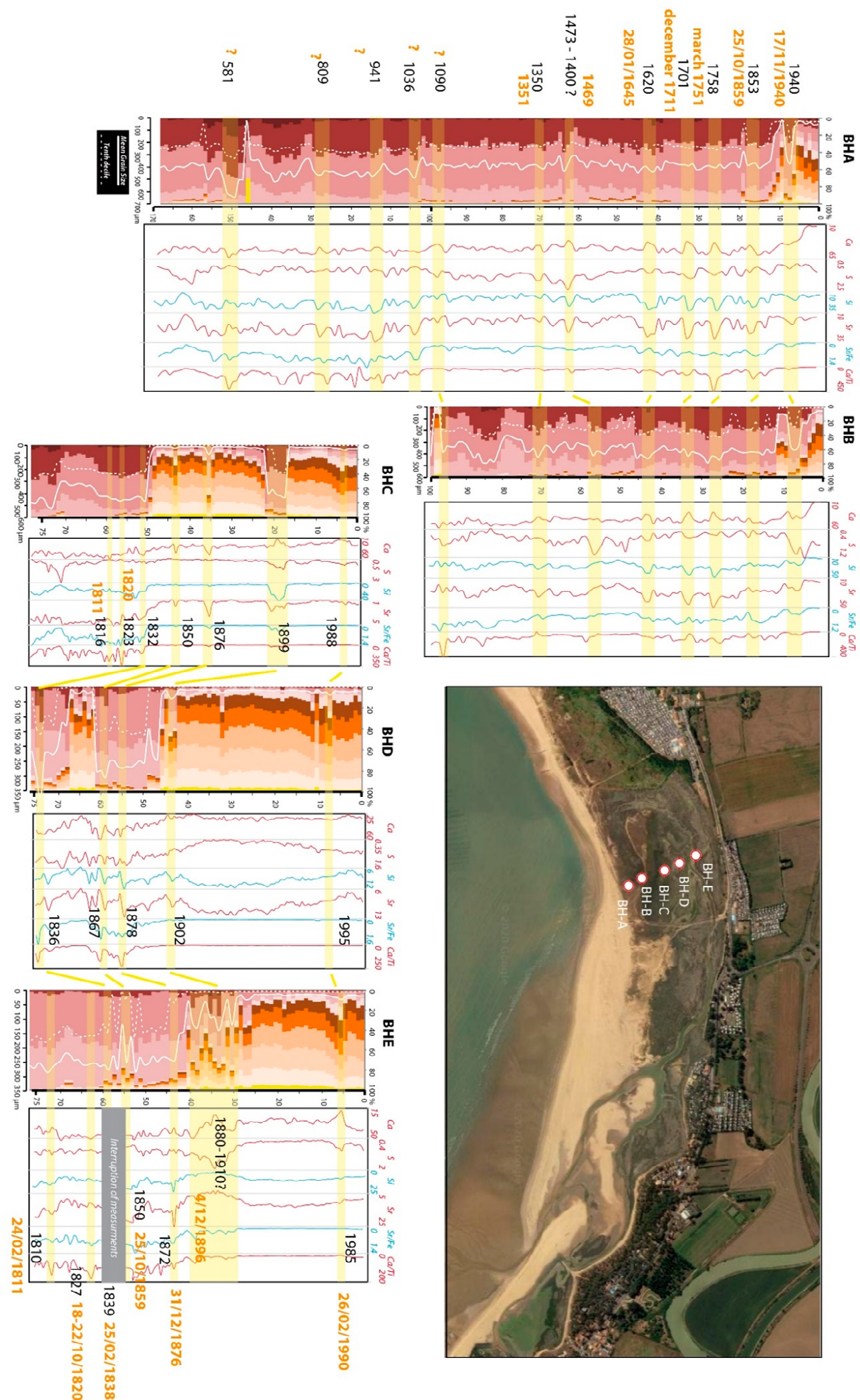

Figure 9. Detection of marine layers linked to historical storms found in archives. The five cores show different storm proxies: grain size data (sands proportions with the red gradient; silts proportions with the orange gradient; clay proportions in yellow; and MGS in the solid line and the tenth decile in chest line) and geochemical results ( $\mathrm{Ca}, \mathrm{S}, \mathrm{Sr}, \mathrm{Si}, \mathrm{Sr} / \mathrm{Fe}$, and $\mathrm{Ca} / \mathrm{Ti})$. The marine layers are highlighted in yellow, with their isotopic dating in black. Related past extreme event hypothetical dates extracted from historical sources are written in orange. The aerial photograph was extracted from Google Earth. 


\subsubsection{Post-1900 Events}

The first storm recorded in the archives refers to the event of 26-28 February 1990. From the historical archives, we learned that three storms hit the study area in 1990, causing a lot of damage. One of them recorded a strong tide gauge of 104 at the port of Pouliguen (SHOM) during the event of 26-28 February 1990. The port is located two kilometres south of the Traicts du Croisic. These three successive high-profile storms caused more than 100 deaths in France, with winds up to $176 \mathrm{~km} / \mathrm{h}$ in the west. Numerous reports of flooded houses and broken dikes were also recorded. The wind damage was considerable: fallen trees, pylons, walls, cranes, and billboards; collapsed church steeples, torn roofs, crushed cars, and numerous traffic accidents [13].

The event of 16-17 November 1940 was also evident in the cores; historical data reveals the strength of a storm that killed 30 people in 1940 recorded in the sediments. The winds resulted in considerable damage: trees uprooted, towers and dikes destroyed, and major damage to boats and roofs. Numerous marine submersions were also identified.

\subsubsection{XIXth-Century Events}

Six storms that occurred during the XIXth century were recorded in the five cores. One of the most significant is associated with the event of 4 December 1896. Numerous breaches were identified along the Atlantic coastline. The event resulted in 33 deaths in France due to numerous storm-generated floods. It was combined with a strong tide gauge of about 95 according to the SHOM. We hypothesize that this significant event of 1896 affected much of the French Atlantic coast, since three cores from the Belle Henriette lagoon were affected, and all nine cores from the Petite Mer de Gâvres and Traicts du Croisic lagoons [13]. In the Petite Mer de Gâvres, the event may have breached the coastal spit that isolates the lagoon from the ocean. Through a paleoenvironmental reconstruction of the study area, we can assume that the event contributed to the progradation of the coastal spit D, which resulted in the establishment of the Belle Henriette lagoon.

The five other impacts are less evident in the sediments but were nonetheless considerable according to historical sources. A storm occurred on 31 December 1876 during a syzygy tide impacting the Loire-Atlantique: breach of a $2 \mathrm{~km}$ stretch of dike with $6 \mathrm{~km}$ of the embankment needing to be rebuilt, submerged marshes, state intervention, and repairs to the salt marshes of Guérande, Mesquer, and Pouliguen totalling FRF 380,000. The cost of the damage caused by the storm at Croisic and Guérande was estimated at over FRF 3 million; we discovered that residents required help to rebuild and it was still being discussed in 1880. During the two-day storm that started on 25 October 1859 with an estimated coefficient of 100, winds reached over $118 \mathrm{~km} / \mathrm{h}$. The affected areas were the departments bordering the Atlantic Ocean and the English Channel. We estimated around 800 deaths (90 damaged vessels and 133 individual drownings). Waves invaded fields and salt marshes with the equivalent of 6 years' loss of work [45,49]. On 24 February 1838, a storm called 'vimer' was reported in Charente-Maritime with heavy rains in Loire-Atlanique in the preceding days, which resulted in the Loire flooding [45]. On 18 October 1820, a three-day storm with significant winds affected Brittany, Charente-Maritime, Vendée, and Loire-Atlantique. Several accidents at sea and deaths through drowning (four boat fatalities) were reported, and many boats were destroyed $[43,45]$. The last storm of the 19th century occurred late in the afternoon on 24 February 1811, with a flood lasting more than $12 \mathrm{~h}$ at high tide. Two deaths were reported, along with breaches of the dikes at Le Croisic and Bouin. Half the island was submerged on Bouin, with the loss of salt and salt pans which were under water for more than $12 \mathrm{~h}$. The loss of salt was estimated at around 1/3 of the total production [45].

\subsubsection{Older Significant Events}

The five older impacts refer to the storms of 17 March 1751, 9 December 1711, 28 January 1645, 27-28 January 1469, and the winter of 1351-1352. All five storms pro- 
foundly impacted the socioeconomic coastal communities; details of these storms were reported by Pouzet and Maanan (2020) [4].

During the 1751 storm, marine flooding was reported on the former island of Bouin and in Les Sables-d'Olonne. Wind impacts were recorded in Nantes and Thouars and Legé was severely affected, according to the Francheteau family records. In La Ploueze, the damage was so severe that people thought it was accompanied by an earthquake. The storm also had a significant impact off shore; at the request of the consulates, the Admiralty of Nantes issued an order to all boat owners on 17 March 1751 to unload their cargo within $24 \mathrm{~h}$ and set sail from Paimboeuf as quickly as possible. Their mission was to assist ships stranded by the storm and recover the merchandise. According to this source, the Admiralty's aim was to reduce the damage to trade caused by the storm. The parish register for Nantes reports that only three of the 60 ships remained unharmed and that many people were injured or died.

During the 1711 event, a strong storm surge was observed in La-Faute-sur-Mer [50]. Historical records report significant damage, such as the destruction of dikes and flooding of salt marshes. The total cost is estimated at 1.19 million euros in modern currency, mainly because the repairs to the dikes took so long. Ré Island was severely flooded. After the storm, salt production tools were discovered near the forecourt of the Portes en Ré church. According to local parish records, the storm and its associated marine flooding profoundly affected coastal families for centuries. One written source called this event a 'hurricane' after the Thouars bell tower collapsed into the church vault.

In 1645, marine flooding was reported in the marshes of the Ré, Aix, and Oléron islands and in the cities of La Rochelle, Marennes, Arvert, and Saint-Sornin. A large vessel was destroyed in the lowlands at an altitude of $3 \mathrm{~m}$ NGF and nearly 30 vessels sank. Reported by Athimon (2021), these impacts are recorded in the regional archives of Charente, Charente-Maritime, Gironde, and Sarthe and in local historical books. The storm is referred to as 'cloudy', 'horrible', and 'terrible', and a large proportion of the residents affected referred to it as 'exceptional'. In terms of the economic cost, it took the people of Ré Island three months to repair the damage that affected agricultural activities. The overall spatial extent of the storm was considerable and included much of the French Atlantic coast.

Concerning the event of 1469 , the tidal coefficient is estimated as being around 106 (spring tide) on 28 January. The storm in 1469 caused severe damage to the dikes and salt marshes of what was the island of Bouin, which was submerged during the night. Historical data indicates that 1,500 tonnes of salt were likely lost, with 30-m long breaches of the salt marsh pavements. Numerous ridges and roads were destroyed and a salt merchant was drowned. In the Retz region, maritime floods can be detected through the records of taxes that merchants were required to pay to their lord (seigneurial taxes). The land had become barren due to the brutal marine incursions and prices fell as a result. Its effects were mainly felt on the coast (from central Vendée to the south of Brittany).

The last event recorded relates to the winter of 1351-1352. Many lowlands on Noirmoutier Island were flooded for nearly half a century. The marshes were also destroyed in Olonne, and salt production was still affected 15 years later. This event was defined as a major submersion of Ré Island and 'probably apocalyptic'. Athimon (2021) described the storm as 'one of the most violent and dramatic weather events of the last millennium along the French Atlantic coast'. Sedimentological and historical evidence highlights its impact in Brittany to the Pertuis Charentais. They also suggest that this storm may have hit the British Isles, meaning that much of the European Atlantic Coast was affected [4].

\section{Discussion}

\subsection{Challenges Associated with Crossing Sedimentological Data and Historical Storm Archives}

As presented in Figure 9, eighteen marine facies were extracted from the five cores. However, when crossing their isotopic dating with the precise date of storm occurrences recorded in historical archives, only thirteen of them (1990, 1940, 1896, 1876, 1859, 1838, 
$1820,1811,1751,1711,1645,1469$, and 1351) were confirmed as past storm events. The key sedimentological parameters used to detect marine layers are high mean grain size, tenth decile, sand, or coarse sand rates and high geochemical values for $\mathrm{Sr} / \mathrm{Fe}$ and $\mathrm{Ca} / \mathrm{Ti}$. The historical data presented in the results section proves that each of these storms entailed significant marine conditions causing coastal flooding. Significant socioeconomic impacts were also reported, attesting to the significance of these historical disasters. The five other dates $(1090,1036,941,809$, and 581) go back further than the period covered by the study of historical sources; they cannot be definitively confirmed as historical storms, but the hypothesis can be discussed. According to Bryant (2005) [51], tsunamis affecting the eastern Atlantic coast account for about $1.5 \%$ of total tsunamis recorded in the seas and oceans worldwide. The hypotheses of past tsunami signatures cannot be disregarded as they have already been discussed by some European studies, but tsunamis are less likely to occur than storms [52,53].

In addition, there are several challenges associated with crossing these two methods. Reconstructions are based on information gathered, and gaps in the information, especially documentaries, therefore influence the reconstruction, the results, and the interpretation. For example, although sedimentological impacts of past storms can be detected between 1420 and 1470, the historical archives from this period are insufficient to confirm several hypotheses [45]. Sedimentological archives also have wider margins of error than historical ones. Added to this, extratropical events are lower in intensity than tropical cyclones and therefore harder to identify in sedimentary records. A combination of parameters for intense marine-weather events is therefore required to identify impacts on coastal macrotidal depositional environments [6].

\subsection{Spatial Extent of Storms}

Other studies carried out by the OR2C reflect the often vast spatial extent of events detected in the sedimentological archives. The storms of 1940, 1896, 1751, 1469, and 1351 were detected at the Belle Henriette, but also left their mark in the Traicts du Croisic and the Petite Mer de Gâvres [4,13]. According to these two studies, the event of 1990 detected at the Belle Henriette also impacted these two environments, but to a much lesser extent (few cores were impacted). The events of 1711 and 1645 detected in the five cores from the Anse des Rouillères were also detected elsewhere, but only at the Traicts du Croisic, leaving a significant mark [4]. In terms of the events of 1876, 1838, and 1811 at the Belle Henriette, hypotheses were proposed at the Traicts du Croisic during these periods [13]. However, the dating is not accurate enough to support these assumptions. Finally, sedimentological analyses suggest that both the 1859 and 1820 events seem to have affected only the Belle Henriette region, but historical archives insist on how violent it was. Since the Belle Henriette site is located further south than the two others, the two storms may have taken a more southerly route through the country than the other historical events recorded. In terms of the other older hypotheses for 1090,941,581, and 809, these can be linked respectively with the hypothetical events detected at the Traicts of Croisic in $1083 \pm 30,973 \pm 44$, and $522 \pm 60$, and at the Petite Mer de Gavres in $768 \pm 230$ [4]. However, the event dated 1036 does not match the work previously carried out by our research team. On a wider scale, the event of 581 can be linked to the 1590 cal yBP storm phase detected on Yeu Island, and all, or nearly all, the events of 581, 809, and 941 are included in an EASE (European Atlantic Stormy Event) [54]. Historical records generally provide limited information on storm damage linked to a precise location. Consequently, it is difficult to document storm tracks from historical sources.

\subsection{Storms Detected in a Changing Environment}

As Figure 2 shows, the Belle Henriette site has undergone profound changes in recent centuries: (i) what was once the Gulf of Pictons was filled by the ocean during the transgression linked to the interglacial Holocene; (ii) it was then filled by alluvial deposits from major rivers and the succinct progression of sandy spits along the shoreline, until 
the present time, where the environment is (iii) a lagoon cut off from the ocean. The sedimentological approach based on statistical analyses of the geochemical characteristics of the sediments enabled storm events to be tracked in different sedimentary environments (gulf, bay, and lagoon). For this study, we used two ratios associated with grain size: $\mathrm{Sr} / \mathrm{Fe}$ and $\mathrm{Ca} / \mathrm{Ti}$ ( $\mathrm{Sr}$ and $\mathrm{Ca}$ are elements of maritime origin; $\mathrm{Fe}$ and $\mathrm{Ti}$ are from the bedrock) [55-58].

Several studies have shown that these extreme events of the past are detectable in bays [59-61], due to the impulse of significant marine levels revealed by coarser sediments than those in bays. This configuration is identifiable from the $20 \mathrm{~cm}$ of cores $\mathrm{BH}-\mathrm{A}$ and $\mathrm{BH}-\mathrm{B}$ and the $50 \mathrm{~cm}$ of cores $\mathrm{BH}-\mathrm{C}, \mathrm{BH}-\mathrm{D}$, and $\mathrm{BH}-\mathrm{E}$. The configurations of the Anse des Terres Noires and the Belle Henriette lagoon are therefore conducive to the detection of washovers since the environment is muddy or silty and extreme events are detected by the incidence of sandy and marine elements (such as Sr and Ca) [6,32,62]. The distinction is therefore much clearer between a lagoon environment and an allochthonous marine facies (rich in Fe and Ti). From these five cores, the lagoon environment was detected in the first 20 centimetres of the $\mathrm{BH}-\mathrm{A}$ and $\mathrm{BH}-\mathrm{B}$ cores and the first 50 centimetres of the $\mathrm{BH}-\mathrm{C}, \mathrm{BH}-\mathrm{D}$, and $\mathrm{BH}-\mathrm{E}$ cores. Regardless of the sedimentary environment, the peaks in these two reports describe an extreme event. This result is confirmed by historical archives. Despite the significant changes to the landscape, the method of detecting historical storms proposed by the Regional Coastal Risk Observatory (OR2C) works with different types of environments.

\section{Conclusions}

Despite significant environmental changes in the study area, the proposed approach has produced satisfying results in different types of coastal environments. In addition to providing information on historical storms, the sedimentological archives illustrate the various successive paleoenvironmental phases. From the cores collected at the Belle Henriette lagoon, thirteen ancient storms were detected, mainly through precise analysis of grain size and geochemical proxies. By cross-referencing with historical archives, these storms can be estimated as having occurred in 1990, 1940, 1896, 1876, 1859, 1838, 1820, $1811,1751,1711,1645,1469$, and 1351. Hypotheses can also be discussed for older events dated 1090, 1036, 941, 809, and 581. Historical records are unable to confirm these, but several links with other storm phases have been detected on a wider scale (EASE). By cross-referencing with previous studies carried out at our laboratory, the storms of 1990, 1940, 1896, 1751, 1469, and 1351 were also identified in the Petite Mer de Gâvres (southern Brittany) and Traicts du Croisic, (Loire-Atlantique), those of 1876, 1838, 1811, 1711, and 1645 were also identified at the Traicts du Croisic, and those of 1859 and 1820 were only recorded at the Belle Henriette lagoon. The spatial extent of these historical events can therefore be discussed. Researchers involved in developing risk and uncertainty methods should consider the wider environmental context carefully. Crossing sedimentological data with historical archives is a challenge and is harder to adopt in changing environments. Decision makers should understand why different approaches may give different estimates of risk assessment.

Author Contributions: M.M., M.R, P.P. conceived the idea of the study, carried out fieldwork campaigns, and wrote the paper; M.M., P.P. and S.S. performed the analyses, and processed the results and the analytical discussions; M.M. and M.R. took part in analytical discussions and managed the research project. All authors have read and agreed to the published version of the manuscript.

Funding: Analyses: operating costs and field measurements were funded by the DREAL (Direction Régionale de l'Environnement, de l'Aménagement et du Logement) of the Pays-de-la-Loire and the UMS CNRS 3281 OSUNA (Observatoire des Sciences de l'Univers de Nantes Atlantique) through the research program OR2C-AXE3 (History of Coastal Risk, reference dreao2rc).

Institutional Review Board Statement: Not applicable.

Informed Consent Statement: Not applicable. 
Data Availability Statement: The datasets generated during and/or analysed during the current study are available from the corresponding author on reasonable request.

Acknowledgments: The authors gratefully acknowledge Emmanuelle Athimon from the CRHIA (EA 1163 Centre de Recherches en Histoire Internationale et Atlantique of the University of Nantes) for her help during the analyses of historical written archives for the five major storms developed. Authors also gratefully acknowledge Loïc Bourdy, Bastien Gruchet, Riwan Kerguillec, and Martin Juigner for their help during the fieldwork campaigns; and Isabelle Billy and her sedimentary core technical team of the UMR CNRS 5805 EPOC (Environnements et Paléoenvironnements Océaniques et Continentaux, University of Bordeaux) for XRF spectrometric core scanner analysis.

Conflicts of Interest: The authors declare no conflict of interest.

\section{References}

1. IPCC. IPCC Special Report on the Ocean and Cryosphere in a Changing Climate; IPCC: Geneva, Switzerland, 2019.

2. Wahl, T. Sea-level rise and storm surges, relationship status: Complicated! Environ. Res. Lett. 2017, 12, 111001. [CrossRef]

3. Intergovernmental Panel on Climate Change. Climate Change 2014: Impacts, Adaptation and Vulnerability: Part A: Global and Sectoral Aspects: Working Group II Contribution to the IPCC Fifth Assessment Report; Cambridge University Press: Cambridge, UK, 2014.

4. Pouzet, P.; Maanan, M. Climatological influences on major storm events during the last millennium along the Atlantic coast of France. Sci. Rep. 2020, 10, 12059. [CrossRef] [PubMed]

5. Chaumillon, E.; Bertin, X.; Fortunato, A.; Bajo, M.; Schneider, J.-L.; Dezileau, L.; Walsh, J.P.; Michelot, A.; Chauveau, E.; Créach, A.; et al. Storm-induced marine flooding: Lessons from a multidisciplinary approach. Earth-Sci. Rev. 2017, 165, 151-184. [CrossRef]

6. Pouzet, P.; Maanan, M. Temporal approaches of historical extreme storm events based on sedimentological archives. J. Afr. Earth Sci. 2020, 162C, 103710. [CrossRef]

7. Donnelly, J.P.; Butler, J.; Roll, S.; Wengren, M.; Webb, T. A backbarrier overwash record of intense storms from Brigantine, New Jersey. Mar. Geol. 2004, 210, 107-121. [CrossRef]

8. Liu, K.; Fearn, M.L. Reconstruction of Prehistoric Landfall Frequencies of Catastrophic Hurricanes in Northwestern Florida from Lake Sediment Records. Quat. Res. 2000, 54, 238-245. [CrossRef]

9. May, S.M.; Brill, D.; Engel, M.; Scheffers, A.; Pint, A.; Opitz, S.; Wennrich, V.; Squire, P.; Kelletat, D.; Brückner, H. Traces of historical tropical cyclones and tsunamis in the Ashburton Delta (north-west Australia). Sedimentology 2015, 62, 1546-1572. [CrossRef]

10. Yu, K.-F.; Zhao, J.-X.; Shi, Q.; Meng, Q.-S. Reconstruction of storm/tsunami records over the last 4000 years using transported coral blocks and lagoon sediments in the southern South China Sea. Quat. Int. 2009, 195, 128-137. [CrossRef]

11. Bozzano, G.; Kuhlmann, H.; Alonso, B. Storminess control over African dust input to the Moroccan Atlantic margin (NW Africa) at the time of maxima boreal summer insolation: A record of the last 220 kyr. Palaeogeogr. Palaeoclimatol. Palaeoecol. 2002, 183, 155-168. [CrossRef]

12. Oliveira, F.; Macario, K.; Simonassi, J.; Gomes, P.; Anjos, R.; Carvalho, C.; Linares, R.; Alves, E.; Castro, M.D.; Souza, R.; et al. Evidence of strong storm events possibly related to the little Ice Age in sediments on the southerncoast of Brazil. Palaeogeogr. Palaeoclimatol. Palaeoecol. 2014, 415, 233-239. [CrossRef]

13. Pouzet, P.; Maanan, M.; Schmidt, S.; Athimon, E.; Robin, M. Correlating three centuries of historical and geological data for the marine deposit reconstruction of two depositional environments of the French Atlantic coast. Mar. Geol. 2019, 407, 181-191. [CrossRef]

14. Sorrel, P.; Debret, M.; Billeaud, I.; Jaccard, S.L.; McManus, J.F.; Tessier, B.; Jaccard, S. Persistent non-solar forcing of Holocene storm dynamics in coastal sedimentary archives. Nat. Geosci. 2012, 5, 892-896. [CrossRef]

15. Kylander, M.E.; Söderlindh, J.; Schenk, F.; Gyllencreutz, R.; Rydberg, J.; Bindler, R.; Cortizas, A.M.; Skelton, A. It's in your glass: A history of sea level and storminess from the Laphroaig bog, Islay (southwestern Scotland). Boreas 2020, 49, 152-167. [CrossRef]

16. Degeai, J.-P.; Devillers, B.; Dezileau, L.; Oueslati, H.; Bony, G. Major storm periods and climate forcing in the Western Mediterranean during the Late Holocene. Quat. Sci. Rev. 2015, 129, 37-56. [CrossRef]

17. Wolanski, E.; Brinson, M.M.; Cahoon, D.R.; Perillo, G.M. Coastal Wetlands: Integrated Ecosystem Approach; Elsevier Science: Amsterdam, The Netherlands, 2009; 974p.

18. Pouzet, P.; Maanan, M.; Schmidt, S.; Dieulefet, G.; Large, J.M.; Robin, M. Évolutions paysagères et occupations humaines passées du Marais poitevin occidental durant la fin de l'Holocène. Géomorphol. Relief Process. Environ. 2021, 27, $263-278$.

19. Kerguillec, R.; Audère, M.; Baltzer, A.; Debaine, F.; Fattal, P.; Juigner, M.; Launeau, P.; Le Mauff, B.; Luquet, F.; Maanan, M.; et al. Monitoring and management of coastal hazards: Creation of a regional observatory of coastal erosion and storm surges in the pays de la Loire region (Atlantic coast, France). Ocean Coast. Manag. 2019, 181, 104904. [CrossRef]

20. Stéphan, P.; Goslin, J. Holocene relative sea-level rise along the atlantic and English Channel coasts of france: Reassessment of existing data using 'sea-level index points' method. Quaternaire 2014, 25, 295-312. [CrossRef]

21. Pouzet, P. Etude des Paléoévènements Extrêmes le Long de la Côte Atlantique Française: Approches Sédimentologiques, Dendrochronologiques et Historiques. Ph.D. Thesis, Université de Nantes, Nantes, France, 2018. 
22. Migeon, S.; Weber, O.; Faugeres, J.-C.; Saint-Paul, J. SCOPIX: A new X-ray imaging system for core analysis. Geo-Mar. Lett. 1998, 18, 251-255. [CrossRef]

23. Gee, G.W.; Or, D. 2.4 Particle-Size Analysis. In SSSA Book Series; Dane, J.H., Topp, C.G., Eds.; Soil Science Society of America: Madison, WI, USA, 2002; pp. 255-293. [CrossRef]

24. Kilmer, V.; Alexander, L. Methods of making mechanical analyses of soils. Soil Sci. 1949, 68, 15-24. [CrossRef]

25. Blott, S.J.; Pye, K. Gradistat: A grain size distribution and statistics package for the analysis of unconsolidated sediments. Earth Surf. Process. Landf. 2001, 26, 1237-1248. [CrossRef]

26. Folk, R.L.; Ward, W.C. Brazos River Bar: A Study in the Significance of Grain Size Parameters. J. Sediment. Res. 1957, 27, 3-26. [CrossRef]

27. Liu, K.; Fearn, M.L. Lake-sediment record of late Holocene hurricane activities from coastal Alabama. Geology 1993, 21, 793-796. [CrossRef]

28. Budillon, F.; Esposito, E.; Iorio, M.; Pelosi, N.; Porfido, S.; Violante, C. The geological record of storm events over the last 1000 years in the Salerno Bay (Southern Tyrrhenian Sea): New proxy evidences. Adv. Geosci. 2005, 2, 123-130. [CrossRef]

29. Bouchard, F.; Francus, P.; Pienitz, R.; Laurion, I. Sedimentology and geochemistry of thermokarst ponds in discontinuous permafrost, subarctic Quebec, Canada. J. Geophys. Res. Biogeosci. 2011, 116, 14.

30. Martin, L.; Mooney, S.; Goff, J. Coastal wetlands reveal a non-synchronous island response to sea-level change and a palaeostorm record from $5.5 \mathrm{kyr}$ to present. Holocene 2014, 24, 569-580. [CrossRef]

31. Chagué-Goff, C. Chemical signatures of palaeotsunamis: A forgotten proxy? Mar. Geol. 2010, 271, 67-71. [CrossRef]

32. Sabatier, P.; Dezileau, L.; Colin, C.; Briqueu, L.; Bouchette, F.; Martinez, P.; Siani, G.; Raynal, O.; von Grafenstein, U. 7000 years of paleostorm activity in the NW Mediterranean Sea in response to Holocene climate events. Quat. Res. 2012, 77, 1-11. [CrossRef]

33. Yamasoe, M.A.; Artaxo, P.; Miguel, A.H.; Allen, A.G. Chemical composition of aerosol particles from direct emissions of vegetation fires in the Amazon Basin: Water-soluble species and trace elements. Atmos. Environ. 2000, 34, 1641-1653. [CrossRef]

34. Appleby, P.G. Chronostratigraphic techniques in recent sediments. In Tracking Environmental Change Using Lake Sediments, Basin Analysis, Coring, and Chronological Techniques; Last, W.M., Smol, J.P., Eds.; Kluwer Academic Publishers: Dordrecht, The Netherlands, 2001; Volume 1.

35. Praet, N.; Moernaut, J.; Van Daele, M.; Boes, E.; Haeussler, P.J.; Strupler, M.; Schmidt, S.; Loso, M.G.; De Batist, M. Paleoseismic potential of sublacustrine landslide records in a high-seismicity setting (south-central Alaska). Mar. Geol. 2017, 384, 103119. [CrossRef]

36. Goldberg, E.D. Geochronology with lead-210. In Radioactive Dating; International Atomic Energy Agenc: Vienna, Austria, 1963; pp. 121-131.

37. Robbins, J.A.; Krezoski, J.R.; Mozley, S.C. Radioactivity in sediments of the Great Lakes: Post-depositional redistribution by deposit-feeding organisms. Earth Planet. Sci. Lett. 1977, 36, 325-333. [CrossRef]

38. Zoppi, U. Radiocarbon AMS Data Analysis: From Measured Isotopic Ratios to 14C Concentrations. Radiocarbon 2010, 52, 165-170. [CrossRef]

39. Reimer, P.J.; Bard, E.; Bayliss, A.; Beck, J.W.; Blackwell, P.G.; Ramsey, C.B.; Buck, C.E.; Cheng, H.; Edwards, R.L.; Friedrich, M.; et al IntCal13 and Marine13 Radiocarbon Age Calibration Curves 0-50,000 Years cal BP. Radiocarbon 2013, 55, 1869-1887. [CrossRef]

40. Tisnérat-Laborde, N.; Paterne, M.; Métivier, B.; Arnold, M.; Yiou, P.; Blamart, D.; Raynaud, S. Variability of the northeast Atlantic sea surface $\triangle 14 \mathrm{C}$ and marine reservoir age and the North Atlantic Oscillation (NAO). Quat. Sci. Rev. 2010, 29, 2633-2646. [CrossRef]

41. Athimon, E. Vimers de Mer et Sociétés Dans les Provinces de la Façade Atlantique du Royaume de France (XIVe-XVIIIe s). Ph.D. Thesis, Université de Nantes, Nantes, France, 2019.

42. Garnier, E.; Henry, N.; Desarthe, J. Visions croisées de l'historien et du courtier en réassurance sur les submersions. Recrudescence de l'aléa ou vulnérabilisation croissante? In Gestion des Risques Naturels, Leçons de la Tempête Xynthia; Quae: Versailles, France, 2012; pp. 105-128.

43. Garnier, E.; Surville, F. La tempête Xynthia Face à L'histoire; Submersions et Tsunamis sur les Littoraux Français du Moyen Âge à nos Jours; Le Croît Vif Ed.: Issy-les-Moulineaux, France, 2010.

44. Sauzeau, T. L'histoire des tempêtes et la prospective littorale face aux changements climatiques, 18 p. In «S'adapter à la mer: Homme la mer et le littoral du moyen âge à nos Jours» Éd PUR Rennes, Frances; University Presses of Rennes: Rennes, Frances, 2014; pp. 71-88.

45. Athimon, E. Tempêtes et Submersions Marines Dans les Territoires de la Côte Atlantique (XIVe-XVIIIe Siècle); Savantes, I., Ed.; 2021; 450p. Available online: https://journals.openedition.org/abpo/7129 (accessed on 10 December 2021).

46. Athimon, E.; Maanan, M. Vulnerability, resilience and adaptation of societies during major extreme storms during the Little Ice Age. Clim. Past Discuss. 2018, 14, 1487-1497. [CrossRef]

47. Sarrazin, J.-L. «Vimers de mer» et sociétés littorales entre Loire et Gironde (XIVe-XVIe siècle). Norois Environ. Aménage. Société 2012, 222, 91-102. [CrossRef]

48. Sarrazin, J.-L.; Athimon, E. Étudier les plus anciennes tempêtes à submersion identifiées sur la côte atlantique française (xive-xvie siècles): L'approche historique. Norois Environ. Aménage. Société 2019, 2, 27-42. [CrossRef]

49. Buron, G. Bretagne des Marais Salants. Tome 2, Hommes du sel; Skol Vreizh: Morlaix, France, 2000. 
50. Garnier, E.; Ciavola, P.; Spencer, T.; Ferreira, O.; Armaroli, C.; McIvor, A. Historical analysis of storm events: Case studies in France, England, Portugal and Italy. Coast. Eng. 2018, 134, 10-23. [CrossRef]

51. Bryant, E. Natural Hazards; Cambridge University Press: Cambridge, UK, 2005.

52. Abrantes, F.; Alt-Epping, U.; Lebreiro, S.; Voelker, A.; Schneider, R. Sedimentological record of tsunamis on shallow-shelf areas: The case of the 1969 AD and 1755 AD tsunamis on the Portuguese Shelf off Lisbon. Mar. Geol. 2008, 249, 283-293. [CrossRef]

53. Dawson, A.G.; Hindson, R.; Andrade, C.; Freitas, M.D.C.P.D.; Parish, R.; Bateman, M. Tsunami sedimentation associated with the Lisbon earthquake of 1 November AD 1755: Boca do Rio, Algarve, Portugal. Holocene 1995, 5, 209-215. [CrossRef]

54. Pouzet, P.; Maanan, M.; Piotrowska, N.; Baltzer, A.; Stéphan, P.; Robin, M. Chronology of Holocene storm events along the European Atlantic coast: New data from the Island of Yeu, France. Prog. Phys. Geogr. Earth Environ. 2018, 42, 431-450. [CrossRef]

55. Cailleux, A. Distinction des sables marins et fluviatiles. Bull. Société Géol. Fr. 1943, S5-XIII, 125-138. [CrossRef]

56. Mercier, D. Géomorphologie de la France; Dunod: Malakoff, France, 2013.

57. Klein, C. Massif Armoricain et Bassin Parisien. In Contribution à L'étude Géologique et Géomorphologique d'un Massif Ancien et de ses Enveloppes Sédimendaires (Normandie, Maine, Anjou, Tourain, Poitou Septentrional et Contrées Adjacentes); Université de Bretagne Occidentale: Brest, France, 1975.

58. Debelmas, J.; Mascle, G.; Basile, C. Les Grandes Structures Géologiques, 5th ed.; Dunod: Malakoff, France, 2008.

59. Khouakhi, A.; Snoussi, M.; Niazi, S.; Raji, O. Vulnerability assessment of Al Hoceima bay (Moroccan Mediterranean coast): A coastal management tool to reduce potential impacts of sea-level rise and storm surges. J. Coast. Res. 2013, 1, 968-973. [CrossRef]

60. Naquin, J.D.; Liu, K.; McCloskey, T.A.; Bianchette, T.A. Storm deposition induced by hurricanes in a rapidly subsiding coastal zone. J. Coast. Res. 2014, 70, 308-313. [CrossRef]

61. Suanez, S.; Stéphan, P. Forçages météo-marins et dynamique morphosédimentaire saisonnière des cordons dunaires. Exemple de la baie de Saint-Michel-en-Grève (Côtes d'Armor, Bretagne). Géomorphol. Relief Process. Environ. 2006, 12, 91-110. [CrossRef]

62. May, S.M.; Brill, D.; Leopold, M.; Callow, J.; Engel, M.; Scheffers, A.; Opitz, S.; Norpoth, M.; Brückner, H. Chronostratigraphy and geomorphology of washover fans in the Exmouth Gulf (NW Australia) - A record of tropical cyclone activity during the late Holocene. Quat. Sci. Rev. 2017, 169, 65-84. [CrossRef] 